\title{
Okul öncesi çocukların empati bölümleri ile annelerinin ebeveyn tutumları arasındaki ilişkinin incelenmesi
}

\section{The examination of the relationship between the empathy sections of the preschool children and the parental attitudes of their mothers}

\section{Makale Geçmişi \\ Geliş : :26 Ağustos 2019 \\ Düzeltme : 1 Nisan 2020 \\ Kabul : 15 Nisan 2020}

\section{Makale Türü}

Araștırma Makealesi

\section{Article History}

Received : 26 August 2019

Revised : 1 April 2020

Accepted : 15 April 2020

\section{Article Type}

Research Article

\author{
Meral Taner Derman ${ }^{1}$, Şeyma Türen ${ }^{2}$, Türkane Buntürk ${ }^{3}$
}

\begin{abstract}
Öz: Bu araștırmanın amacı; annelerin ebeveyn tutumları ile çocuklarının empati bölümleri arasındaki ilişkinin incelenmesidir. Araştırmada ilişkisel tarama modeli kullanılmıştır. Araştırmanın çalışma grubu, resmi anaokullarına devam etmekte olan 5-6 yaş gruplarındaki toplam 142 okul öncesi çocuk ve onların annelerinden oluşmaktadır. Araştırmada Kişisel Bilgi Formu, Ebeveyn Tutum Ölçeği ve Çocuklar İçin Empati Bölümü Ölçeği kullanılmıştır. Verilerin analizi için Kruskall Wallis H ve Mann Whitney U testleri ve Spearman korelasyon analizi uygulanmıştır. Araştırma sonucunda; çocukların duygusal ve bilişsel empati bölümlerinin annelerinin eğitim düzeylerine göre, çocukların davranışsal empatisinin ise ailelerinin gelir durumuna göre farklılaştığ görülmektedir. Çocukların duygusal empatileri ve genel empati becerileri ile annelerinin demokratik tutumları arasında pozitif ilişki; çocukların duygusal, davranışsal ve genel empati becerileri ile annelerinin otorier tutumu arasında negatif ilişki; çocukların duygusal empati bölümü ile annelerinin izin verici tutumları arasında da negatif ilişki olduğu bulunmuştur. Eğitim ve gelir düzeyi düşük olan annelere, empatinin önemi ve çocuk gelişimine etkileri konularında seminerler verilmesi önerilmektedir.
\end{abstract}

Anahtar Kelimeler: Okulöncesi, Çocukta empati, Empati bölümleri, Ebeveyn tutumu

Abstract: The purpose of this research was to examine the relationship between parental attitudes of mothers and empathy sections of children. Correlational study was relized. The study group consisted of 142 preschool children and their mothers in 5-6 age groups who was attending official kindergartens. This study included Personal Information Form, Parent Attitude Scale and Empathy Section Scale for Children. For data analysis, Kruskall Wallis H and Mann Whitney U tests and Spearman correlation analysis were used. As a result of the research; it was observed that emotional and cognitive empathy of children differed based on the education level of their mothers and children's behavioral empathy differed in terms of their families' income status. It was observed that there was a positive relationship between emotional empathy and general empathy skills of children and their mother's democratic attitudes; a negative relationship between emotional, behavioral and general empathy skills of children and authoritarian attitudes of their mothers; a negative association between the emotional empathy of children and the permissive attitudes of their mothers. The mothers with low education and income levels can be acknowledged with the seminars about the importance of the empathy and its effects on the child development.

Keywords: Preschool, Empathy in children, Empathy sections, Parental attitudes 


\section{SUMMARY}

\section{Introduction}

Empathy; it's defined as an individual's ability to understand the feelings, thoughts and desires of consciousness by putting itself in place of another consciousness (TDK, 2012). The sections of empathy consist of cognitive, emotional and behavioral empathy. Köksal (2005) states that empathy develops in a certain process and its first symptoms extend until infancy. The role of parents responsible for the child in the development of empathy is very important (Önder, 2015).

All of the behaviors that parents exhibit towards their children while raising their children are called parental attitudes (Toksöz, 2010). From parental attitudes; In democratic attitude, parents are concerned with their children and the child is given the right to speak in the family. In authoritarian attitudes, children are expected to follow the rules set by parents, and children are punished when they don't (Baumrind, 1966). In permissive attitude; all requests of children are accepted without any supervision or limitation (Dönmezer, 2001). In overprotective attitude; many things that children can do are done by the family and they are prevented children from learning through their own experiences (Alisinanoğlu, 2003).

When studies investigating parents' attitudes and the effects of these attitudes on children were examined, it was seen that there wasn't study examining the relationship between mothers' parental attitudes and episodes of empathy in children. Since there weren't studies examining such a relationship, it is thought that this research will contribute to the field. In this respect, the overall aim of the research was to examine the relationship between the empathy sections of preschool children and their mothers' parental attitudes.

\section{Method}

In the research, correlational study was realized. A total of 142 pre-school children and their mothers, 65 from Bursa and 77 from Istanbul, in the 5-6 age groups, who are attending formal kindergartens selected by simple non-selective sampling method, participated in the study.

The scales used in the research: "Parental Attitude Scale", "Empathy Scale for Children" and "Personal Information Form.” Parent Attitude Scale: The scale developed by Karabulut-Demir and Şendil (2008) consists of 4 sub-dimensions and 46 items, including democratic, authoritarian, overprotective and permissive. Empathy Section Scale for Children: The scale, which was adapted in Turkish by Dinç Altun, Değerli, Çıkrıkçı and Kınık (2018), consists of 3 sub-dimensions and 14 items, including emotional, behavioral and cognitive empathy. Personal Information Form: In the form prepared by the researchers, consists of parents' age, education level, occupation, economic status, number of children and ages of their children. 
In order to analysis of the data collected in the study, firstly, it was looked at whether it showed normal distribution using the Kolmogorov-Smirnov Z test. Kruskal Wallis-H and Mann Whitney U tests were performed because it didn't show normal distribution. In addition, Spearman correlation analysis was conducted to determine the relationship between parental attitudes and the empathy section scale for child.

\section{Results}

As a result of the research, empathy sections of children were not affected by the age of theirs parents, the number of siblings and the age of the child. It was determined that the emotional and cognitive empathy of children showed a significant difference in favor of graduates with their undergraduate degree according to the education level of their mothers. In addition, it is observed that the children of families with good income are more resourceful in behavioral empathy section. Parental attitudes of mothers aren't affected by their age, number of children and age of their children. It was determined that mothers who graduated from primary school and secondary school had a more protective attitude. It was also determined that mothers with good incomes were more democratic.

It has been observed that the level of emotional empathy and general empathy of their children increases as mothers' democratic attitude increases. It has been identified that as mothers ' authoritarian attitude increases, their children's emotional, behavioral, and overall empathy level decreases. In addition, It was concluded that as mothers' permissive attitudes increased, their children's level of emotional empathy decreased.

\section{Conclusion and Discussion}

In the light of the findings, in favor of mothers with a bachelor's degree in emotional and cognitive empathy of children; It was determined that behavioral empathy showed significant differences in favor of those with good income. Taner Derman (2013) stated that children's empathy status varies according to maternal education level. Aslan (2018) found that children's empathy was significantly higher in families in the upper income group. According to the results obtained in the study, it was thought that the children of mothers with high educational level and income status have the ability to understand emotions and thoughts and that they are an example to their children by exhibiting empathetic behaviors.

The democratic attitude is in favor of those who are good in terms of the income status of the family; the overprotective attitude differs statistically in terms of the maternal educational status of mothers who graduate from primary and secondary education. Aydoğdu and Dilekmen (2016) found that mothers who graduated from secondary schools were more overprotective than parents who graduated from undergraduate and graduate schools. Eroğlu (2014) stated that families with children between the ages of 06 are more democratic and egalitarian towards their children as the income level increases. Mothers who are 
economically comfortable are thought to adopt a more democratic attitude by giving more responsive and appropriate feedback to their children.

As the mother's democratic attitude increased, emotional empathy increased the level of general empathy; emotional, behavioral and general empathy level decreased with increasing authoritarian attitude; as the permissive attitude increased, the level of emotional empathy decreased. Parsak (2015) found a significant relationship between children's empathy levels and parental attitudes in his research. Children are thought to exhibit empathetic or non-empathetic behavior by exemplifying the democratic/authoritarian behavior of their mothers.

In the light of the results, seminars can be given to mothers with low educational level and families with low socioeconomic status and suggestions were made to prepare scales measurinh mothers' empathic skills due to lack of resources in this field. 


\section{GİRİŞ}

Empati; ilk olarak 19. yüzyılın ortalarında Robert Vischer (1873) tarafından "Einfühlüng” kelimesi kullanılarak ifade edilmiştir. Einfühlüng; sanat eserlerinin, seyircilerin kas ve duygu durumlarını etkileyebildiklerini ve dolayısıyla farklı duygu dünyalarına girebilmelerine olanak tanıması olarak yorumlanmıştır.

Literatüre bakıldığında empati kavramı psikolojide ilk defa Lipps tarafindan 1897 yılında kullanılmıştır. Lipps, empati kavramını; nesneyi inceleyen ve gözlemleyen kişilerin, kendilerini nesneye yansıtması ve bu nesneyle özdeşim kurmaları olarak açıklamıştır (Barret-Lennard, 1981). 1909 yllında Titchener, Almanca "einfühlüng” olarak adlandırılan kelimeyi İngilizce’ye "empathy" şeklinde çevirmiştir. Böylece empatinin psikoloji ve psikiyatri tarihine girişi gerçekleşmiştir (Gallese, 2003).

Empati, birçok bilim dalları tarafından incelendiği için açıklaması güç bir kavramdır. Tarih boyunca çeşitli boyutlarda ve farklı anlamlarda tanımlamaya çalışılmıştır. Ancak pek çok araştırmacının üzerinde uzlaştığı Rogers'ın tanımı olmuştur (Mete, 2005). Empati kavramının; psikoterapi/psikolojik danışma süreçlerinde ve günlük hayatta bireyler arası iletişimdeki yerini ve önemini, en etkili bir biçimde açıklayıp kullanan bilim insanı Carl Rogers’tır. Rogers'a göre danışan merkezli psikolojik danışma kuramında; danışma sürecinde danışmanın danışanı koşulsuz kabul etmesi, diğer yandan da danışanda kişilik değişimi sağlayabilmek için danışmanın empati kurması gerekmektedir. Danışmanın empati kurabilmesi için, danışanın duygu ve düşüncelerini onun bakış açısıyla anlaması ve danışanın gözüyle değerlendirmesi gerekmektedir. Bunu yapabilmek için ise danışman, kendi görüş ve değerlerini bir yana bırakarak, önyargısız ve yargılamadan danışanın dünyasına girebilmelidir (Emery, 1987; Gladstein ve Feldstein, 1983).

Türk Dil Kurumu (2012) yaptığ1 tanımda empatinin, sözcük anlamını; duygudaşlık olarak çevirmiş ve bireyin kendisini başka bir bilincin yerine koyarak bu bilincin duygu, düşünce ve isteklerini anlayabilme becerisi olarak açıklamıştır. Dökmen’e (2014) göre duygu ve düşünceler doğru olarak anlaşı1sa bile eğer karşıdaki kişiye onu anladığı ifade edilmezse empati kurma süreci tamamlanmamış sayılır. Yani empatide ilk önce kişinin kendisini karşısındakinin yerine koyması ve olaylara onun bakış açısıyla bakması sonrasında karşıdaki kişinin duygu ve düşüncelerini doğru olarak anlaması ve en son olarak da kişinin zihninde oluşan empatik anlayışı karşısındaki kişiye iletme süreci vardır. 


\section{Empati Gelişimi}

Geçmiş yıllara bakıldığında, kuramcılar; empati konusunda küçük çocukların çok benmerkezci oldukları ve gerekli bilişsel yeterlilikte olmadıklarını savunmuşlardır. Bu kuramcılardan Piaget, yaşamın ilk yıllarında sahip olunan benmerkezci düşünce nedeniyle bebeklerin başkalarının duygu ve düşüncelerini anlayamadıkları fikrini ileri sürmüştür. Ancak bu fikrin tersine yapılan çok sayıda çalışma çok küçük çocukların empati konusunda oldukça gelişmiş davranışlarda bulunduğunu ortaya koymuştur (Zahn-Waxler, Radke-Yarrow ve King, 1979; Zahn-Waxler, Radke-Yarrow, Wagner \& Chapman, 1992). Hoffman (1987) ve Damon (1988) gibi gelişim psikologları çocukların iki yaşından sonra çevrelerindeki ipuçlarını değerlendirdiklerini, çevresindekilerin duygusal ifadelerine benmerkezci olmayan tepkiler gösterdiklerini ve empati kurabildiklerini belirtmişlerdir.

Empati diğer gelişim alanlarındaki gibi belirli bir süreç içerisinde gelişir ve ilk belirtilerine bakıldığında bebeklik dönemine kadar uzanabilmektedir. 0-1 yaş arasında bulunan bebekler, başkalarının üzüntülerine tepki verirler ancak o kişilerin üzüldügünün farkında olduklarını belli etmezler. 1-2 yaşlarında ise kişinin üzüntülü olduğunu anlayabilirler ama burada da kişinin kendisinden farklı ihtiyaçlarının olabileceğinin farkında olmadıkları için uygun tepkiler göstermeyebilirler. 2- 10 yaş aralığında çocuklar, diğer kişilerin duygularının, kendisininkinden farklı olduğunun farkına varmaya ve kendi gereksinimlerini belirleyerek olaylara kendi yorumlarını katmaya başlarlar (Köksal, 2005). Çocuklar kendilerini karşısındaki kişinin yerine koymaya altı yaşından itibaren başlayabilirler (Akbaş ve Temiz, 2015; Önder ve Gülay, 2007).

\section{Empatinin Bileşenleri}

Bilişsel Empati: Duyguların bilişsel olarak anlaşılması durumudur. Bilişsel empatide, başkalarının duygularını yaşamak söz konusu değildir. Staub (1990), bilişsel empatiyi; diğer kişilerin duygu, düşünce, niyet ve içsel durumlarının bilişsel açıdan anlaşılması olarak tanımlamıştır. Empatiye ait bu bileşen dikkatli gözlemi ve düşünmeyi gerektirmektedir. Gürtunca’ya (2013) göre, bilişsel empatide, kişilerin duygu ve düşüncelerini sözel veya sözel olmayan ipuçları ile anlama becerisi vardır.

Duyuşsal Empati: Empatinin, duyuşsal bileşeni dikkate alınmadığında bu kavram sadece diğer insanın yaşantısını tanıma ve etiketleme becerisi olarak kalır (Eisenberg ve Strayer, 1987). Duygusal empati, empati kurulan kişi ve birey arasında sağlanan duygusal deneyim olarak yorumlanır (Yıldırım, 2003). Kuramcılar empatinin bu yönünü tanımlarken, karşısındaki kişinin duygularına duyarlı olma durumu ve paylaşma becerisi olarak açıklamışlardır (Gürtunca, 2013). 
Davranıssal Empati: Kişinin kendi davranışları ile karşısındakinin davranışlarını, kendi konumu ile karşısındakinin konumunu bilmesi ve ona göre davranışlarda bulunması empatinin davranışsal boyutu olarak tanımlanabilir. Empatinin bu boyutu, kişilerin kendisini bu konuda eğitmesine bağlı olarak gelişir. Davranışsal empatisi olan olmayanın ayırımını bir örnek ile açıklamak gerekirse; davranışsal empatiye sahip kişi adres tarif ederken "sağa git" dediğinde karşı tarafın sağını gösterir. Kendisini karşısındakinin yerine geçirip yönlendirme yapar. Ancak davranışsal empatisi olmayan kişi ise "sağa git" derken kendi sağını gösterir (Tarhan, 2013).

\section{EBEVEYN TUTUMLARI}

Anne ve babaların çocuklarını büyütürken onlara karşı sergiledikleri davranışların tümü "ebeveyn tutumları" olarak adlandırılmaktadır (Toksöz, 2010). 1930 yılından bu yana, anne babaların, çocuk yetiştirme tutumlarını belirlemek üzere birçok araştırmacı tarafından çalışmalar yürütülmüş ve sınıflandırmalar yapılmıştır. Bunlardan biri olan Symonds (1939) ebeveynlerin çocuk yetiştirme tutumları ile ilgili ilk kez bir sınıflandırma yapılmıştır. Bu sınıflandırma kabul etme-reddetme ve baskınlık-itaat etme olarak iki boyuttadır (Akt. Şanlı ve Öztürk, 2015). Baumrind (1971), ebeveynlik tutumlarını kontrol ve kabul boyutlarıyla açıklamış ve bu boyutlar doğrultusunda demokratik, otoriter ve izin verici olmak üzere üç ebeveyn tutumundan bahsetmiştir. Maccoby ve Martin (1983), çalışmalarında Baumrind tarafından yapılan bu sınıflandırmadan yola çıkarak izin verici ebeveyn boyutuna bir alt boyut daha eklemişlerdir. Ekledikleri bu alt boyut ile izin verici ebeveynlik sınıflandırılmasını; izin veren ebeveyn ve ihmal edici ebeveyn olarak iki farklı türde genişletmişlerdir.

Anne ve babalar, çocukların yaşamları boyunca önemli bir yere ve etkiye sahiptirler. Dolayısıyla çocukların ebeveynlerinden gördükleri tutumlar, çocukların gelişimlerini etkilemektedir (Özdal, 2003). Çocukların ruhsal açıdan sağlıklı olması, kendine güven duyması ebeveyn tutumlarına bağlıdır (Çetinkaya, 2018). Olumlu ebeveyn tutumları, çocukların hem kendisi hem de içinde yaşadıkları topluma yararlı bireyler olmalarına katlı sağlar (Yörükoğlu, 2015).

Anne babaların ebeveynlik tutumları; anne babanın yaşı, eğitim durumu, anne ve babanın yetiştirilme tarzları, ailenin gelir durumu, aile tipi, çocuk sayısı; çocuğun yaşı, cinsiyeti, mizacı ve içinde bulundukları toplumun kültürel etkileri gibi birçok değişkenden etkilenir. Bu değişkenler sonucunda ebeveyn tutumları aileden aileye farklılık gösterebildiği gibi aynı aile içerisinde anne ve baba davranışlarında bile farklılı̆̆a neden olmaktadır (Axinn \& Thornton, 1993; Atabey, 2017; Aydoğdu ve Dilekmen, 2016; Efe Azkeskin, Güven, Güral ve Sezer, 2013; Grusec \& Danyliuk, 
2014; Özyürek ve Tezel Şahin, 2005; Tatlı, Selimoğlu ve Bademci, 2012; Tezel Şahin ve Özyürek, 2008; Şanlı ve Öztürk, 2012).

\section{Demokratik Anne Baba Tutumu:}

Demokratik ebeveyn tutumunda, çocuk; bir birey olarak kabul edilirken kendi kararlarını vermesi ve deneme yanılma yaparak öğrenme süreci desteklenmektedir. Çocuğun duygu ve düşüncelerine değer verilir. Aile ortamında kurallar belirlenir ve çocuk bu kurallar dâhilinde özgürdür (Alisinanoğlu, 2003; Aydoğdu ve Dilekmen, 2016). Ebeveynler çocuklarını dinleyerek onlara karşı ilgilidirler. Aile içinde çocuklara da söz hakkı verilmektedir (Baumrind, 1966).

Çocuklar, anne babaları tarafindan kendi ilgi, yetenek ve değerleri doğrultusunda yönlendirilip desteklenir. Böyle bir ailede yetişen çocuklar, genellikle kendilerini gerçekleştirmiş bireyler olurlar. Kendi gerçekleştirmiş bireyler ise psikolojik açıdan sağlıklı ve çağdaş insanda olması gereken özellerine sahip olurlar (Çetinkaya, 2018). Ayrıca bu çocuklar geçmişten çok geleceğe yönelen, yaratıcı, kendini kabul edip duygularını açıklayan, kendine ve çevresine saygılı, hoşgörülü, dengeli, sorumluluk duygusu gelişmiş, girişken ve açı fikirli, değişime ve yeni yaşantılara açı olurlar (Çetinkaya, 2018; Kaya, Bozaslan ve Genç, 2012). Bu tutum anne baba tutumları arasında, çocukların kişilik gelişimi için en sağlıklı ve uygun olan tutumdur (Özdemir, Güzel Özdemir, Kadak ve Nasiroğlu, 2012).

\section{Otoriter Anne Baba Tutumu:}

Otoriter ebeveyn tutumunda, denetim oldukça yüksekken çocukların ilgi ve ihtiyaçlarına gösterilen tepki veya duyarlılık düşüktür. Bu aile ortamında çocukların kişisel özellikleri, ilgi ve gereksinimleri pek dikkate alınmayarak çocukların istekleri bastırılmaya çalışılır. Sert bir disiplin anlayışı söz konusudur. (Dönmezer, 2001). Anne babalar, çocuklar ile görüş alışverişinde bulunmazlar. Ebeveynler tarafından konulan kurallara çocukların mutlaka uymaları gerekir. Çocuklar kurallara uymadiklarında cezalandırliır (Baumrind, 1966).

Otoriter ortamda yoğun uygulanan ceza, çocukların vicdani gelişimlerini olumsuz olarak etkileyebilir. Böyle bir ortam çocukların kendine güvenlerini azaltırken suçluluk duygusuna kapılmalarına neden olabilir. Verilen cezalar fiziksel ve sürekli olması bazı çocuklarda aileye karşı asi ve dışarıda da kavgacı olmasına sebep olabilmektedir. Aynı zamanda çocuklar, kolay yalan söyleyebilme, çalma davranışları görülebilirler, okul ve sosyal yaşamında başarısızlıklar olabilir (Çetinkaya, 2018). Bu çocukların kendilerine saygıları düşük olurken kayg1 düzeyleri yüksektir. 
Yaşadıkları bu benlik sorunlarının yanında ilişkilerinde onay ararlar ve psikolojik olarak uyum sorunlar1 yaşayabilirler (Sümer, Gündoğdu Aktürk ve Helvac1, 2010).

\section{İzin Verici Anne Baba Tutumu:}

İzin verici ebeveyn tutumunda, çocuklar herhangi bir kontrol ve denetime tabi tutulmadan özgür bir şekilde hareket etmektedir (Aydoğdu ve Dilekmen, 2016). Genellikle çocukların tercihlerine karışılmaz ve çocuklar kendi istekleri zamanlarda yemek, uyku, oyun gibi faaliyetlerini gerçekleştirirler (Baumrind, 1966). Toplumsal kurallara pek önem verilmediği için bunlar çocuklara öğretilmez. Çocuklar kurallara uymadığında herhangi bir cezalandırma uygulanmaz. Uygulandığ durumlarda da cezalar yetersiz kalarak çocuklar tarafindan ciddiye alınmayabilir. Bu aileler çocuklarının her türlü taleplerini herhangi bir denetleme ya da sınırlama olmaksızın kabul ederler (Dönmezer, 2001).

İzin verici ebeveynlerde bazen ihmale varan bir hoşgörü görülmektedir. İzin verici tutum ile yetiştirilen çocuklarda zayıf dürtü kontrolü ve düşük akademik başarı görülebilir. Bu çocuklarda sorumluluk alma konusunda isteksizlik olurken yüksek düzeyde benmerkezcilik gözlenebilir (Afat, 2013). Çocuklar içinde bulundukları her ortamda aile içindeki rahatllğı bulamayabileceği için tedirginlik ve huysuzluk yaşarlar. Aynı zamanda bu tutumda, çocukların davranışlarına pek tepki gösterilmemesi, çocuklarda; anne babasının kendisine karşı ilgisiz olduğu düşüncesine kapılmasına sebep olabilir (Aydoğdu ve Dilekmen, 2016).

\section{Aş1rı Koruyucu Anne Baba Tutumu:}

Aşırı koruyucu ebeveyn tutumunda; çocukların yapabileceği pek çok şey aile tarafından yapılarak çocukların kendi deneyimleri ile öğrenmeleri engellenir. Bu aile ortamında, çocuklar; olması gerekenden çok fazla kontrol altına alınırlar (Alisinanoğlu, 2003).

Aşırı korunarak büyütülen çocuklar, kendine güvenleri zayıf ve bağımlı kişilik özellikleri geliştirirler. Özgün hareket etmek ve karar vermekte güçlük çekerek anne baba ya da bir başkasının yönlendirmesine ihtiyaç duyarlar. Sorunlarla baş ederken zorlanabilir, hatta güçlükler yaşadıklarında nevrotik belirtiler gösterebilirler (Yörükoğlu, 2019). Ailelerin aşırı koruyuculuğu çocukların okula uyumlarını ve okuldaki başarılarını da etkileyebilir. Ayrıca böyle bir ortamda yetişen çocuklarda utangaçlık problemiyle de karşılaşılmaktadır (Rubin \& Burgess, 2002). 


\section{Empati Gelişiminde Anne Babanın Rolü}

Empati gelişimde, çocukların yaşamının önemli bir zamanı geçirdiği ev ortamı ve bu ortamda çocuktan sorumlu olan ebeveynlerin rolü reddedilemez. Çocukların doğumundan sonra başlayıp ilk yılında tamamlanan çocuk ve anne arasındaki sağlık bağlanma ilişkisi, her zaman empatik gelişim ile doğrudan ilişkili değildir. Ancak sağlıklı bağlanan çocukların, empatinin öğrenilen kısmı olan başkalarıyla ilgilenme, başkalarının duygularını önemseme ve onlanı rahatlatmaya çalışma gibi davranışlarda bulunma ihtimalinin daha yüksek olduğu söylenebilir. Ayrıca ileri sürülen diğer bir görüşe göre; çocuklar ve anneleri arasında sonraki yıllarda kurulan sıcak ve yakın ilişki, çocukların çevresindeki diğer kişilerle olumlu sosyal ilişkiler kurmasını etkilemektedir (Zhou, Eisenberg, Losoya, Fabes, Reiser, Guthrie, Murphy, Cumberland \& Shepard, 2002).

Çocukları sürekli eleştirip düzeltmek yerine, onları dinleyen ve anlamaya çalışan ebeveynlerin varlığ1 empati gelişimi açısından önemli bulunmaktadır. Bu tür ebeveynler, çocuklarının hissettiklerine ve yaşadıklarına önem verdiklerini gösterir ve bunu çocuklarına hissettirler. Dinlenen, kendisine sayg1 duyulan ve kabul edici ebeveynlerini gören çocuklar da başka kişileri dinlemeye ve onların kendi duygularını kabul etmeye yönelirler (Overland, 2012: Akt. Önder, 2015). Çocuklar ev ortamlarında, ebeveynleri arasında empatik davranışlar gözlemliyorsa, kendisi için en etkin model olan ebeveynlerinin bu davranışını taklit yoluyla kazanma ihtimali oldukça yüksektir. Ebeveynlerin iyi birer model olmaları konusunda eğitilmeleri gerekmektedir (Önder, 2015).

0-6 yaş çocuklarda empati gelişimi, ileriki yaşlarında sosyal çevreleri açısından önemli bir yer tutmaktadır. Fakat okul öncesi çocuklarda empati konusunda yapılan araştırmaların bir kısmı bu becerinin erken yaşlarda kazandırılabileceğini gösterirken diğer bir kısmı ise bu yaş grubu çocukların empati kurmak için yeterli bilişsel beceriye sahip olamadığına işaret etmektedir (Kahraman, 2007). Ridley, Vaughn ve Wittman (1982) 3,5-5 yaş arası çocuklar ile yaptıkları çalışmada, 6 yaşın altında olan çocukların ben-merkezci olmaları nedeniyle empatik beceri eğitiminden yararlanamayacakları sonucunu elde etmişlerdir. Bu sonuca tezat olarak Şahin ve Karaaslan (2006) tarafindan yapılan 36 yaş grubu çocukların sosyal beceri düzeylerinin incelendiği araştırmada 5-6 yaş grubu çocukların diğer yaş gruplarına göre farklı duygu durumları tespit etmede daha başarılı olduğu sonucuna ulaşmıstır.

Ebeveyn tutumları ve bu tutumların çocuklar üzerindeki önemi uzun yıllardır araştırmacılar tarafından araştırlmaktadır. Ülkemizde de son yllarda ebeveyn tutumları ve bu tutumların çocuklara etkilerini incelemek üzere birçok araştırma yapılmıştır (Afat, 2013; Bedge ve Özyürek, 2016; Durmuşoğlu Saltalı ve Arslan, 2012; İkiz ve Öztürk Samur, 2016; Şahin, Ocak Karabay ve 
Demir, 2017; Temel ve Türkoğlu, 2019). Literatürde yer alan araştırmalara bakıldığında annelerin ebeveyn tutumları ile çocuklardaki empati bölümleri arasındaki ilişkiyi inceleyen bir araştırma olmadığ1 görülmüştür. Daha önce böyle bir ilişkiyi inceleyen çalışma olmaması sebebiyle bu araştırmanın alana katkı sağlayacağı düşünülmektedir. Yürütülecek olan bu araştırmayla annelerin ebeveyn tutumlarını etkileyen değişkenler ile çocukların empati bölümlerini etkileyen değişkenler tespit edilmeye çalışılacak ve aynı zamanda annelerin ebeveyn tutumlarının çocuktaki empati bölümleri ile ilişkisinin olup olmadığı, ilişki varsa bu ilişkinin hangi tutumda ve hangi yönde olduğu konusunda 1şık tutulacaktır. Bu doğrultuda araştırmanın genel amacı; okul öncesi çocukların empati bölümleri ile annelerinin ebeveyn tutumları arasındaki ilişkinin incelenmesidir. Bu genel amaç doğrultusunda aşağıdaki sorulara yanıt aranmaya çalışılmıştır.

1. Çocukların empati bölümleri, anne-baba yaşları, eğitim durumları, ailenin gelir durumuna ve kardeş sayısı değişkenlerine göre farklılaşmakta mıdır?

2. Annelerin ebeveyn tutumları; yaşları, eğitim durumları, gelir durumlarına, çocuklarının yaşı ve çocuk sayısı değişkenlerine göre farklılaşmakta mıdır?

3. Annelerin ebeveyn tutumları ile çocukların empati bölümleri arasında bir ilişki var mıdır?

\section{YÖNTEM}

\section{Araştırma Modeli}

$\mathrm{Bu}$ araştırmada nicel araştırma yöntemlerinden olan ilişkisel tarama modeli kullanılmıştır. İlişkisel tarama modelinde, iki ve daha çok sayıdaki değişken arasında birlikte değissim olup olmadığı ve değişimin derecesi saptanmaya çalışılmaktadır (Karasar, 2013).

\section{Çalışma Grubu}

Araştırmanın çalışma grubunu, 2018-2019 eğitim-öğretim yılında resmi okulöncesi eğitim kurumuna devam eden 5-6 yaş gruplarındaki Bursa ilinden 66 ve İstanbul ilinden 77 olmak üzere toplam 142 çocuk ve bu çocukların anneleri oluşturmaktadır. Bu çalışma grubu basit seçkisiz örnekleme yöntemi ile seçilmiştir. Basit seçkisiz örnekleme yöntemi, çalışma grubuna eşit seçilme olasılığ1 veren bir yöntemdir (Büyüköztürk, Kılıç Çakmak, Akgün, Karadeniz ve Demirel, 2018).

Tablo 1'de, örneklem grubuna ait ebeveynlere dair yaş, eğitim durumu, gelir durumu, çalışma durumu ve anne-babanın birliktelik durumu, çocukların yaş ve kardeş sayılarına dair bilgiler verilmiştir. 
Tablo 1. Demografik bilgiler

\begin{tabular}{|c|c|c|c|}
\hline Değişkenler & Gruplar & $f$ & $\%$ \\
\hline \multirow{6}{*}{ Anne Yaş } & $20-30$ & 39 & 27,4 \\
\hline & $31-35$ & 51 & 35,9 \\
\hline & $36-40$ & 40 & 28,2 \\
\hline & $41-45$ & 8 & 5,6 \\
\hline & $46+$ & 4 & 2,8 \\
\hline & Toplam & 142 & 100 \\
\hline \multirow{6}{*}{ Baba Yaş } & $26-30$ & 15 & 10,6 \\
\hline & $31-35$ & 38 & 26,8 \\
\hline & $36-40$ & 53 & 37,3 \\
\hline & $41-45$ & 23 & 16,2 \\
\hline & $46+$ & 13 & 9,2 \\
\hline & Toplam & 142 & 100 \\
\hline \multirow{7}{*}{ Anne Eğitim Durumu } & İlkokul & 24 & 16,9 \\
\hline & Ortaokul & 12 & 8,5 \\
\hline & Lise & 33 & 23,2 \\
\hline & Ön Lisans & 24 & 16,9 \\
\hline & Lisans & 38 & 26,8 \\
\hline & Lisansüstü & 11 & 7,7 \\
\hline & Toplam & 142 & 100 \\
\hline \multirow{7}{*}{ Baba Eğitim Durumu } & İlkokul & 18 & 12,7 \\
\hline & Ortaokul & 16 & 11,3 \\
\hline & Lise & 54 & 38,0 \\
\hline & Ön Lisans & 13 & 9,2 \\
\hline & Lisans & 35 & 24,6 \\
\hline & Lisansüstü & 6 & 4,2 \\
\hline & Toplam & 142 & 100 \\
\hline \multirow{5}{*}{ Anne Baba Birliktelik Durumu } & Anne-baba birlikte & 135 & 95,1 \\
\hline & Anne-baba ayr1 & 5 & 3,5 \\
\hline & Anne ölü & 1 & 0,7 \\
\hline & Baba ölü & 1 & 0,7 \\
\hline & Toplam & 142 & 100 \\
\hline \multirow{4}{*}{ Gelir Durumu } & Düşük & 10 & 7,0 \\
\hline & Orta & 88 & 62,0 \\
\hline & İyi & 44 & 31,0 \\
\hline & Toplam & 142 & 100 \\
\hline \multirow{3}{*}{ Anne Çalışma Durumu } & Çalışıor & 65 & 45,8 \\
\hline & Çalışmıyor & 77 & 54,2 \\
\hline & Toplam & 142 & 100 \\
\hline \multirow{3}{*}{ Baba Çalışma Durumu } & Çalısı̧ıyor & 136 & 95,8 \\
\hline & Çalış̧ıyor & 6 & 4,2 \\
\hline & Toplam & 142 & 100 \\
\hline \multirow{5}{*}{ Kardeş Sayı1 1} & Tek Çocuk & 47 & 33,1 \\
\hline & 1 Kardeşi Var & 65 & 45,8 \\
\hline & 2 Kardeşi Var & 21 & 14,8 \\
\hline & 3 ve + Kardeşi Var & 9 & 6,3 \\
\hline & Toplam & 142 & 100 \\
\hline \multirow{3}{*}{ Çocuk Yaş } & 5 & 104 & 73,2 \\
\hline & 6 & 38 & 26,8 \\
\hline & Toplam & 142 & 100 \\
\hline
\end{tabular}


Bu araştırmaya 5-6 yaş arası çocuğu olan 142 çocuk ve onların anneleri dahil edilmiştir. Araştırma kapsamına alınan çocukların annelerinin yaşları 20-46+ yaş, babaların ise 26-46+ aralığındadır. Ailelerin eğitim durumlarına dair bulgulara bakıldığında, anne ve babaların eğitim düzeyleri ilkokullise arası annelerde \%48,6, babalarda ise \%62’i oluştururken; ön lisans ve üstü yükseköğretim düzeyi ise annelerde \%51,4, babalarda \%38 olduğu saptanmıştır. Anne-babanın birliktelik durumuna ait bulgularda, ebeveynlerin \%95'nin birlikte olduğu bunun yanı sıra \%3,5'luk ailede anne-babanın ayrı olduğu ve çalışma grubunda $1(\% 0,7)$ anne ile $1(0,7)$ babanın ölmüş olduğu, bu sayının da \%1,4’e denk geldiği görülmektedir. Anne baba çalışma durumu incelendiğinde annelerin çalışma oranının $\% 45,8$, babaların çalışma oranlarının ise \% 05,8 olduğu saptanmıştır. Çalışma grubundaki çocukların \%73,2'si 5 yaş grubunu ifade ederken \%26,8’ini ise 6 yaş grubu oluşturmaktadır. Bu çocukların $\% 66,9$ 'unun kardeşi varken \%33,1'i ise tek çocuktur.

\section{Veri Toplama Araçları}

Araştırmada veri toplama aracı olarak, annelerin ebeveyn tutumlarını ölçmek için Ebeveyn Tutum Ölçeği (ETÖ) ve çocuklardaki empati düzeylerini ölçmek için ise Çocuklar İçin Empati Bölümü Ölçeği (ÇEBÖ) kullanılmıştır. Ayrıca ebeveynlerin demografik özelliklerini belirlemek için Kişisel Bilgi Formu kullanılmıştır

\section{Ebeveyn Tutum Ölçeği (ETÖ)}

Ebeveyn Tutum Ölçeği (ETÖ), Karabulut Demir ve Şendil (2008) tarafindan ebeveynlerin 2-6 yaş arasındaki çocuklarına olan davranışlarını belirlemek için geliştirilmiştir. Ölçek; Demokratik (17 madde) "Cocuğumun kendine özgü bir bakıs açısı olduğunu kabul ederim.", Otoriter (11 madde) "En ufak bir hatasinda, çocuğumu cez̧alandirrmm.", Așır1 Koruyucu (9 madde) “Cocuğumu, hayatın ufak tefek güclüklerinden korurum." ve İzin Verici (9 madde) "Ben bir başkasyyla konusurken çocuğumun araya girmesine iə̌in veririm” olmak üzere 4 alt boyuttan ve 46 maddeden oluşmaktadır. Ölçek, "Her zaman böyledir"; "Çoğunlukla böyledir"; "Bazen böyledir"; "Nadiren böyledir” ve "Hiçbir zaman böyle değildir" şeklinde 5'li likert tipi bir ölçektir. Maddelerin puanlanmasında "Her zaman böyledir" 5, "Hiçbir zaman böyle değildir" ise 1 puan alır. Her boyuttan alınan puanlar ayrı ayrı hesaplanarak her boyut için bir puan elde edilmektedir. Yüksek puan almak o boyutun temsil ettiği davranış şeklini benimsemek anlamına gelmektedir. Ebeveyn Tutum Ölçeği boyutlarının Cronbach alfa güvenirlik katsayıları; demokratik ebeveyn boyutu için .83, otoriter ebeveyn boyutu için .76, aşırı koruyucu ebeveyn boyutu için .75 ve izin verici ebeveyn boyutu için.74’tür (Karabulut Demir ve Şendil, 2008). Kalayc1 (2010), Cronbach alfa güvenirlik katsayısı; $0,60 \leq \alpha<0,80$ değerleri arasında bir değer aldıysa ölçeğin oldukça güvenilir olduğunu ifade etmektedir. Bu çalışmada ise ölçeğin 
Cronbach Alpha güvenirlik katsayısı ise .76 olarak belirlenmiştir. Bu değer de ölçeğin bu çalışma için güvenilir olduğunu göstermektedir.

\section{Çocuklar İçin Empati Bölümü Ölçeği (ÇEBÖ)}

Auyeung ve arkadaşları tarafından (2009) geliştirilmiş olan Çocuklar İçin Empati Bölümü Ölçeği (ÇEBÖ), Dinç Altun, Değerli, Çıkrıkçı ve Kınık (2018) tarafından Türkçe uyarlaması yapılmıştır. Bu ölçek çocukların empati düzeylerini ve bölümlerini ölçmek amacıyla geliştirilmiştir. Orijinal formu 27 maddeden oluşan ölçek geçerlik güvenirlik çalışmaları neticesinde Türkçe formunda 14 maddelik hale getirilmiştir. 3-7 yaş çocuklara uygulanabilen ölçek, Duygusal Empati (5 Madde) "Cocuğum arkadaşlı kurmada sorun yaşar.", Davranışsal Empati (5 Madde) "Cocuğum isteklerini elde etmek için fir̨iksel şiddete başvurma eğilimindedir” ve Bilişsel Empati (4 Madde) “Cocuğum genellikle baə઼ şeylerin diğer insanlar neden çok ü̃dügüüü anlamaz" olmak üzere 3 alt boyuttan oluşmaktadır. Ölçek puanlamasında, "tamamen katılmıyorum" ile "biraz katılmıyorum" seçeneği 0puan, "biraz katılıyorum" 1 puan, "tamamen katılıyorum" ise 2 puan olarak puanlanmaktadır. Ölçekten alınabilecek en düşük puan 0 , yüksek puan ise 28 ' dir. Ancak puanın yüksek olması çocuğun empatik olmadığını göstermektedir. Alınan puan azaldıkça çocukta empatik olma durumu artmaktadır. Çocuklar İçin Empati Bölümü Ölçeğinin Türkçe formunun Cronbach Alpha değeri .73 olarak hesaplanmıştır (Dinç Altun, Değerli, Çıkrıkçı ve Kınık, 2018). Kalaycı'ya (2010) göre Cronbach Alpha güvenirlik katsayısı; $0,60 \leq \alpha<0,80$ değerleri arasında ise ölçek güvenilirdir. Bu çalışmada ise ölçeğin Cronbach Alpha güvenirlik katsayısı .64 bulunmuştur. Bu değer de ölçeğin bu çalışma için güvenilir olduğunu göstermektedir.

\section{Kişisel Bilgi Formu}

Araştırmacılar tarafindan hazırlanan kişisel bilgi formunda, ebeveynlerin yaşları, eğitim seviyeleri, meslekleri, ekonomik durumları, sahip oldukları çocuk sayıları ve çocuklarının yaşları sorulmaktadır.

\section{Verilerin Toplanmasi}

Verilerin toplanması 2018-2019 eğitim öğretim yllının ilk döneminde gerçekleşmiştir. İlk önce kullanılacak ölçekleri geliştiren/uyarlayan araştırmacılardan mail yoluyla uygulama izni alınmıştır. Ölçek uygulama izinleri alındıktan sonra verilerin toplanacağı okullara gidilmiş ve okul idarecileriyle görüşülüp gerekli izinler alınmıştır. Okul idarecilerinden alınan izinler sonrasında, sınıf öğretmenlerine araştırma kapsamı ile ilgili bilgiler verilmiştir. Hem okul idaresi hem de öğretmenlerin gönüllü olarak araştırmaya katılmaları konusunda izinler alındıktan sonra, veliler ile 
görüşülmüştür. Velilerin çocuklarını okuldan aldıkları zamanlarda okullara gidilmiş ve araştırmanın amacı velilere sözel olarak anlatılmıştır. Sözel olarak anlatımdan sonra velilere, bilgilendirilmiş onam formunun da yer aldığı ölçekler verilerek gönüllü olanların doldurmaları, çocuklarının öğretmenlerine teslim etmeleri istenmiş ve bir hafta sonra doldurulmuş ölçeklerin öğretmen aracılığıla geri alınacağı ifade edilmiştir. Çalışmanın yapıldığı zaman içinde çok sayıda anneye verildiği halde araştırmacılara dönen ölçek sayısı az olduğundan, araştırmacılardan birinin de yaşadığ İstanbul ili çalışmaya dahil edilmiştir.

\section{Verilerin Çözümü ve Yorumlanmas1}

Araştırmada toplanan verilerin analizi için SPSS programı ile ilk önce verilerin normal dağılım gösterip göstermediğine bakılmıştır. Bunun için Kolmogorov-Smirnov Z testinden yararlanılmıştır. Literatür incelendiğinde 50'den büyük gruplarda, normalliği incelemek için Kolmogorov-Smirnov Z testi kullanılmaktadır (Büyüköztürk vd., 2018).

Tablo 2. Kolmogorov-Smirnov Z testine göre normallik dağılımının incelenmesi

\begin{tabular}{llccc}
\hline & Alt Boyutlar & İstatistik & $\mathrm{n}$ & $\mathrm{p}$ \\
\hline \multirow{3}{*}{ Çocuklar İçin Empati Bölümü Ölçeği } & Duygusal empati & 0,25 & 142 & 0,000 \\
& Davranışsal empati & 0,23 & 142 & 0,000 \\
& Bilişsel empati & 0,22 & 142 & 0,000 \\
\hline \multirow{3}{*}{ Ebeveyn Tutum Ölçeği } & Demokratik ebeveyn & 0,16 & 142 & 0,000 \\
& Otoriter ebeveyn & 0,15 & 142 & 0,000 \\
& Aşırı koruyucu ebeveyn & 0,10 & 142 & 0,002 \\
\hline
\end{tabular}

Tablo 2'de verilen Kolmogorov-Smirnov Z testi incelendiğinde; Ebeveyn Tutum Ölçeği ve Çocuklar İçin Empati Bölümü Ölçeğinin alt boyutlarının normal dağılım göstermediği görülmektedir. Yapılan test sonucunda, Ebeveyn Tutum Ölçeğinin ve Çocuklar İçin Empati Bölümü Ölçeğinin alt boyutlarının normal dağılım göstermediği görülmüştür. Bu nedenden Kruskall Wallis-H ve Mann Whitney U testleri uygulanmıştır. Ayrıca ebeveyn tutumları ve çocuktaki empati bölümü arasındaki ilişkinin belirlenmesi amacıyla korelasyon analizi yapılmıştır.

\section{BULGULAR}

Bu bölümde, annelerin ebeveyn tutumları ve çocukların empati bölümleri ile anne baba yaşları, eğitim durumları, gelir durumları, anne-babanın birliktelik durumu, çocuk yaşı ve kardeş sayısı değişkenlerine göre farklılık olup olmadığına; annelerin ebeveyn tutumları ve çocuklarının empati bölümleri arasındaki ilişkiye ait bulgulara yer verilmiştir. 
Araştırmada yer alan çocukların sahip oldukları empati bölümünün, anne baba yaş değişkenine göre farklılık gösterip göstermediğinin anlaşılması için çocuklar için empati bölümü ölçeği kullanılarak aldıkları puanların Kruskal Wallis H testine göre sonuçları Tablo 3'de verilmiştir.

Tablo 3. Çocuklar için empati bölümleri ölçeğinden alınan puanların anne-baba yaş değişkenine ilişkin Kruskal Wallis $\mathrm{H}$ testi sonuçları

\begin{tabular}{|c|c|c|c|c|c|c|c|}
\hline Empati Bölümü & Anne/Baba & $\begin{array}{l}\text { Yaş } \\
\text { Grubu }\end{array}$ & $\mathrm{n}$ & Sira ortalamas1 & sd & $\mathrm{X}^{2}$ & $\mathrm{p}$ \\
\hline \multirow{9}{*}{ Duygusal Empati } & \multirow{4}{*}{ Anne } & $20-30$ & 39 & 66,72 & \multirow{4}{*}{3} & \multirow{4}{*}{1,7} & \multirow{4}{*}{0,64} \\
\hline & & $31-35$ & 51 & 75,37 & & & \\
\hline & & $36-40$ & 40 & 69,1 & & & \\
\hline & & $41+$ & 12 & 78,58 & & & \\
\hline & \multirow{5}{*}{ Baba } & $26-30$ & 15 & 50,6 & \multirow{5}{*}{4} & \multirow{5}{*}{8,54} & \multirow{5}{*}{0,07} \\
\hline & & $31-35$ & 38 & 82,89 & & & \\
\hline & & $36-40$ & 53 & 68,04 & & & \\
\hline & & $41-45$ & 23 & 75,5 & & & \\
\hline & & $46+$ & 13 & 69,35 & & & \\
\hline \multirow{9}{*}{ Davranışsal Empati } & \multirow{4}{*}{ Anne } & $20-30$ & 39 & 70,99 & \multirow{4}{*}{3} & \multirow{4}{*}{1,67} & \multirow{4}{*}{0,64} \\
\hline & & $31-35$ & 51 & 69,65 & & & \\
\hline & & $36-40$ & 40 & 70,15 & & & \\
\hline & & $41+$ & 12 & 85,54 & & & \\
\hline & \multirow{5}{*}{ Baba } & $26-30$ & 15 & 80,23 & \multirow{5}{*}{4} & \multirow{5}{*}{6,06} & \multirow{5}{*}{0,19} \\
\hline & & $31-35$ & 38 & 73,36 & & & \\
\hline & & $36-40$ & 53 & 61,53 & & & \\
\hline & & $41-45$ & 23 & 80,33 & & & \\
\hline & & $46+$ & 13 & 81,04 & & & \\
\hline \multirow{9}{*}{ Bilişsel Empati } & \multirow{4}{*}{ Anne } & $20-30$ & 39 & 72,26 & \multirow{4}{*}{3} & \multirow{4}{*}{0,16} & \multirow{4}{*}{0,98} \\
\hline & & $31-35$ & 51 & 70,45 & & & \\
\hline & & $36-40$ & 40 & 72,94 & & & \\
\hline & & $41+$ & 12 & 68,71 & & & \\
\hline & \multirow{5}{*}{ Baba } & $26-30$ & 15 & 84,17 & \multirow{5}{*}{4} & \multirow{5}{*}{1,87} & \multirow{5}{*}{0,76} \\
\hline & & $31-35$ & 38 & 71,04 & & & \\
\hline & & $36-40$ & 53 & 69,44 & & & \\
\hline & & $41-45$ & 23 & 71,72 & & & \\
\hline & & $46+$ & 13 & 66,23 & & & \\
\hline
\end{tabular}

Tablo 3'de görüldüğü gibi çocuklar için empati bölümü ölçeğinin alt boyutları olan duygusal empati, davranışsal empati ve bilişsel empati boyutları ile anne yaşları $\left(\mathrm{x}_{(\mathrm{dye})}^{2}=5,90, \mathrm{sd}=5, \mathrm{p}>, 05 ; \mathrm{x}_{(\mathrm{dve})}^{2}\right.$ $=4,70, \mathrm{sd}=5, \mathrm{p}>, 05 ; \mathrm{x}^{2}$ (be) $\left.=4,22, \mathrm{sd}=5, \mathrm{p}>, 05\right)$ ve baba yaşlant $\left(\mathrm{x}^{2}{ }_{(\mathrm{de})}=8,54, \mathrm{sd}=4, \mathrm{p}>, 05 ; \mathrm{x}_{(\mathrm{dve})}^{2}=6,06\right.$, $\mathrm{sd}=4, \mathrm{p}>, 05 ; \mathrm{x}^{2}$ (be) $\left.=1,87, \mathrm{sd}=4, \mathrm{p}>, 05\right)$ arasında anlamlı bir farklılık olmadığ saptanmıştır. 
Araştırmada yer alan çocukların sahip oldukları empati bölümünün, anne baba eğitim düzeyi değişkenine göre farklılık gösterip göstermediğinin anlaşılması için çocuklar için empati bölümü ölçeği kullanılarak aldıkları puanların Kruskal Wallis H testine göre sonuçları Tablo 4'de verilmiştir.

Tablo 4. Çocuklar için empati bölümü ölçeğinden alınan puanların anne-baba eğitim durumu değişkenine ilişskin Kruskal Wallis H testi sonuçları

\begin{tabular}{|c|c|c|c|c|c|c|c|}
\hline Empati Bölümü & Anne/Baba & Eğitim Durumu & $\mathrm{n}$ & Sira ortalamas1 & $\mathrm{sd}$ & $\mathrm{X}^{2}$ & $\mathrm{p}$ \\
\hline \multirow[t]{2}{*}{ Duygusal Empati } & Anne & $\begin{array}{l}\text { İlkokul } \\
\text { Ortaokul } \\
\text { Lise } \\
\text { Ön lisans } \\
\text { Lisans } \\
\text { Lisansüstü }\end{array}$ & $\begin{array}{l}24 \\
12 \\
33 \\
24 \\
38 \\
11\end{array}$ & $\begin{array}{l}85,48 \\
79,71 \\
76,00 \\
67,29 \\
56,08 \\
81,00\end{array}$ & 5 & 11,32 & $0,045^{*}$ \\
\hline & Baba & $\begin{array}{l}\text { İlkokul } \\
\text { Ortaokul } \\
\text { Lise } \\
\text { Ön lisans } \\
\text { Lisans } \\
\text { Lisansüstü }\end{array}$ & $\begin{array}{c}18 \\
16 \\
54 \\
13 \\
35 \\
6\end{array}$ & $\begin{array}{l}80,75 \\
75,63 \\
78,22 \\
53,00 \\
63,87 \\
56,83\end{array}$ & 5 & 8,19 & 0,15 \\
\hline \multirow{2}{*}{ Davranışsal Empati } & Anne & $\begin{array}{l}\text { İlkokul } \\
\text { Ortaokul } \\
\text { Lise } \\
\text { Ön lisans } \\
\text { Lisans } \\
\text { Lisansüstü }\end{array}$ & $\begin{array}{l}24 \\
12 \\
33 \\
24 \\
38 \\
11\end{array}$ & $\begin{array}{l}75,52 \\
64,17 \\
79,29 \\
79,52 \\
62,79 \\
59,95\end{array}$ & 5 & 5,68 & 0,34 \\
\hline & Baba & $\begin{array}{l}\text { İlkokul } \\
\text { Ortaokul } \\
\text { Lise } \\
\text { Ön lisans } \\
\text { Lisans } \\
\text { Lisansüstü }\end{array}$ & $\begin{array}{c}18 \\
16 \\
54 \\
13 \\
35 \\
6\end{array}$ & $\begin{array}{l}85,92 \\
69,44 \\
74,22 \\
75,12 \\
62,09 \\
56,33\end{array}$ & 5 & 5,64 & 0,34 \\
\hline \multirow{2}{*}{ Bilişsel Empati } & Anne & $\begin{array}{l}\text { İlkokul } \\
\text { Ortaokul } \\
\text { Lise } \\
\text { Ön lisans } \\
\text { Lisans } \\
\text { Lisansüstü }\end{array}$ & $\begin{array}{l}24 \\
12 \\
33 \\
24 \\
38 \\
11\end{array}$ & $\begin{array}{l}78,10 \\
75,75 \\
82,41 \\
77,58 \\
51,30 \\
76,23\end{array}$ & 5 & 13,61 & $0,02 *$ \\
\hline & Baba & $\begin{array}{l}\text { İlkokul } \\
\text { Ortaokul } \\
\text { Lise } \\
\text { Ön lisans } \\
\text { Lisans } \\
\text { Lisansüstü }\end{array}$ & $\begin{array}{c}18 \\
16 \\
54 \\
13 \\
35 \\
6\end{array}$ & $\begin{array}{l}74,22 \\
74,09 \\
81,52 \\
57,08 \\
61,64 \\
55,00\end{array}$ & 5 & 8,35 & 0,14 \\
\hline
\end{tabular}

${ }^{* \mathrm{p}}<.05$

Tablo 4 incelendiğinde, annesi ilkokul mezunu olan çocukların duygusal empati bölümü puan ortalamaları 85,48, ortaokul mezunun olanların 79,71, lise mezunu olanların 76, önlisans mezunu olanların 67,29, lisans mezunu olanların 56,08 ve lisansüstü olanların ise 81 olarak bulunmuştur. Kruskal Wallis $\mathrm{H}$ testi sonucuna göre duygusal empati bölümü alt boyutunda istatistiksel olarak anlamlı farklılık olduğu görülmektedir $\left(\mathrm{x}^{2}{ }_{\text {(dye) }}=11,32, \mathrm{sd}=5 \mathrm{p}<, 05\right)$. Farkın kaynağını görmek için 
yapılan Mann Whitney U Testi sonucunda, annesi ilkokul, lise ve lisansüstü mezunu olanlar ile lisans mezunu olanlar arasında lisans mezunu olan anneler lehine istatistiksel olarak anlamlı farkl11k olduğu görülmüştür. Duygusal empati boyutunda, baba eğitim düzeyine göre istatistiksel olarak anlamlı farklılığa rastlanmamıştır $\left(\mathrm{x}_{(\mathrm{dye})}^{2}=8,19, \mathrm{sd}=5 \mathrm{p}>, 05\right)$.

Çocuklar için empati bölümü ölçeğinin alt boyutları olan, davranışsal empati (dve) bölümü ile anne eğitim düzeyi ile baba eğitim düzeyine göre istatistiksel olarak anlamlı bir farklılık olmadı̆̆1 belirlenmiştir (Anne eğitim düzeyi: $\mathrm{x}_{(\mathrm{dve})}=5,68, \mathrm{sd}=5, \mathrm{p}>, 05$; Baba eğitim düzeyi: $\mathrm{x}_{(\mathrm{dve})}=5,64, \mathrm{sd}=5$, $\mathrm{p}>, 05)$.

Annesi ilkokul mezunu olan çocukların bilişsel empati bölümü puan ortalamalar1 78,10, ortaokul mezunun olanların 75,75, lise mezunu olanların 82,41, önlisans mezunu olanların 77,58, lisans mezunu olanların 51,30 ve lisansüstü olanların ise 76,23 olarak bulunmuştur. Kruskal Wallis $\mathrm{H}$ testi sonucuna göre bilişsel empati bölümü alt boyutunda istatistiksel olarak anlamlı farkl1lık olduğu görülmektedir $\left(\mathrm{x}_{(\mathrm{be})}^{2}=13,61, \mathrm{sd}=5 \mathrm{p}<, 05\right)$. Farkın kaynağını görmek için yapılan Mann Whitney $\mathrm{U}$ Testi sonucunda, annesi ilkokul, ortaokul, lise, önlisans mezunu olanlar ile lisans mezunu olanlar arasında lisans mezunu olan anneler lehine istatistiksel olarak anlamlı farkl11ı olduğu görülmüştür. Baba eğitim düzeyine göre ise bilişsel empati bölümünde istatiksel olarak anlamlı farklllık bulunmadığ belirlenmiştir $\left(\mathrm{x}_{\text {(be) }}^{2}=8,35, \mathrm{sd}=5, \mathrm{p}>, 05\right)$.

Araştırmada yer alan çocukların sahip oldukları empati bölümünün, gelir durumu değişkenine göre farklılık gösterip göstermediğinin anlaşılması için çocuklar için empati bölümü ölçeği kullanılarak aldıkları puanların Kruskal Wallis H testine göre sonuçları Tablo 5'de verilmiştir.

Tablo 5. Çocuklar için empati bölümü ölçeğinden alınan puanların gelir durumu değişkenine ilişkin Kruskal Wallis $\mathrm{H}$ testi sonuçları

\begin{tabular}{ccccccc}
\hline Empati Bölümü & Gelir Durumu & $\mathrm{n}$ & Sira ortalamas1 & sd & $\mathrm{X}^{2}$ & $\mathrm{p}$ \\
\hline \multirow{3}{*}{ Duygusal Empati } & Düsük & 10 & 77,85 & & & \\
& Orta & 88 & 76,45 & 2 & 5,59 & 0,06 \\
& İyi & 44 & 60,16 & & & \\
\hline \multirow{3}{*}{ Davranışsal Empati } & Düsük & 10 & 66,65 & & & \\
& Orta & 88 & 79,13 & 2 & 9,03 & $0,01 *$ \\
& İyi & 44 & 57,34 & & & \\
\hline \multirow{3}{*}{ Bilişsel Empati } & Düsük & 10 & 68,85 & & \multirow{2}{*}{0,12} & 0,94 \\
& Orta & 88 & 72,36 & 2 & 0,12 & \\
\hline
\end{tabular}

${ }^{* \mathrm{p}}<.05$

Tablo 5 incelendiğinde ailesinin gelir durumu düşük olan çocukların için duygusal empati bölümü puan ortalaması 77,85, davranışsal empati bölümüm puan ortalaması 66,85, bilişsel empati bölümü 
puan ortalamas1 68,85; gelir durumu orta olan çocukların duygusal empati bölümü puan ortalaması 76,45, davranışsal empati bölümü puan ortalaması 79,13, bilişsel empati bölümü puan ortalamas1 72,36; gelir durumu iyi olan çocukların duygusal empati bölümü puan ortalaması 60,16, davranışsal empati bölümü puan ortalaması 57,34, bilişsel empati bölümü puan ortalamas1 70,39 olduğu belirlenmiştir. Yapılan Kruskal Wallis H Testi sonucunda ise çocukların duygusal ve bilişsel empati bölümleri ile ailesinin gelir durumu değişkeni arasında anlamlı bir farklılık olmadığı belirlenmiştir $\left(\mathrm{x}_{(\mathrm{dye})}^{2}=5,59, \mathrm{sd}=2, \mathrm{p}>.05 ; \mathrm{x}_{(\mathrm{be})}^{2}=, 118, \mathrm{sd}=2, \mathrm{p}>, 05\right)$. Çocuklar için empati bölümünün diğer alt boyutu olan davranışsal empati bölümünde ise anlamlı bir farklılık olduğu görülmektedir $\left(\mathrm{x}^{2}{ }_{(\mathrm{dve})}=\right.$ 9,03, sd=2, p<,05). Farklılığın hangi gruptan kaynaklandığı anlamak için yapılan Mann Whitney U testi sonucunda gelir durumu iyi olan grubun, gelir durumu orta olan gruba göre anlamlı derece farklılaştığı sonucuna ulaşılmıştır $(\mathrm{p}<, 05)$. İyi gelir durumu olan ailelerden gelen çocukların davranışsal empati bölümünün orta gelir grubuna göre daha iyi olduğu anlaşılmaktadır.

Araştırmada yer alan çocukların sahip oldukları empati bölümünün, kardeş sayısı değişkenine göre farklılık gösterip göstermediğinin anlaşılması için çocuklar için empati bölümü ölçeği kullanılarak aldıkları puanların Kruskal Wallis H testine göre sonuçları Tablo 4'de verilmiştir.

Tablo 6. Çocuklar için empati bölümü ölçeğinden alınan puanların kardeş sayısı değişkenine ilişkin Kruskal Wallis $\mathrm{H}$ testi sonuçları

\begin{tabular}{|c|c|c|c|c|c|c|}
\hline Empati Bölümü & Kardeş Sayısı & $\mathrm{n}$ & Sira ortalamas1 & $\mathrm{sd}$ & $\mathrm{X}^{2}$ & $\mathrm{p}$ \\
\hline Duygusal Empati & $\begin{array}{c}\text { Kardeşi Yok } \\
1 \\
2+\end{array}$ & $\begin{array}{l}47 \\
65 \\
30\end{array}$ & $\begin{array}{l}65,78 \\
71,42 \\
80,65\end{array}$ & 2 & 2,76 & 0,25 \\
\hline Davranışsal Empati & $\begin{array}{c}\text { Kardeşi Yok } \\
1 \\
2+\end{array}$ & $\begin{array}{l}47 \\
65 \\
30\end{array}$ & $\begin{array}{l}67,26 \\
73,84 \\
73,08\end{array}$ & 2 & 0,81 & 0,67 \\
\hline Bilişsel Empati & $\begin{array}{c}\text { Kardeşi Yok } \\
1 \\
2+\end{array}$ & $\begin{array}{l}47 \\
65 \\
30\end{array}$ & $\begin{array}{l}70,33 \\
69,28 \\
78,13\end{array}$ & 2 & 1,06 & 0,59 \\
\hline
\end{tabular}

${ }^{*} \mathrm{p}<.05$

Tablo 6'da görüldüğgu gibi çocuklar için empati bölümü ölçeğinin alt boyutları olan duygusal empati, davranışsal empati ve bilişsel empati bölümlerinin kardeş sayısı değişkenine göre istatistiksel olarak anlamlı bir farklllık göstermediği belirlenmiştir $\left(\mathrm{x}^{2}{ }_{(\mathrm{dye})}=2,76, \mathrm{sd}=2, \mathrm{p}>, 05 ; \mathrm{x}^{2}{ }_{(\mathrm{dve})}=0,81, \mathrm{sd}=2, \mathrm{p}>, 05\right.$; $\left.\mathrm{x}^{2}(\mathrm{be})=1,06, \mathrm{sd}=2, \mathrm{p}>, 05\right)$.

Araştırmada yer alan çocukların sahip oldukları empati bölümünün yaş grubu değişkenine göre farklılık gösterip göstermediğinin anlaşılması için çocuk empati bölümü ölçeği kullanılarak aldıkları puanların Mann-Whitney U Testine göre sonuçları Tablo 7'de verilmiştir. 
Tablo 7. Çocuklar için empati bölümü ölçeğinden alınan puanların yaş grubu değişkenine ilişkin MannWhitney U testi sonuçları

\begin{tabular}{|c|c|c|c|c|c|c|c|}
\hline Empati Bölümü & Yaş Grubu & $\mathrm{n}$ & Siralar Ortalaması & Stralar Toplam1 & $\mathrm{U}$ & Z & $\mathrm{p}$ \\
\hline \multirow[b]{2}{*}{ Duygusal Empati } & 5 Yaş & 104 & 68,79 & 7154,00 & \multirow[b]{2}{*}{1694,00} & \multirow[b]{2}{*}{$-1,39$} & \multirow[b]{2}{*}{0,16} \\
\hline & 6 Yaş & 38 & 78,92 & 2999,00 & & & \\
\hline \multirow[b]{2}{*}{ Davranışsal Empati } & 5 Yaş & 104 & 72,37 & 7526,50 & \multirow[b]{2}{*}{1885,50} & \multirow[b]{2}{*}{$-0,43$} & \multirow[b]{2}{*}{0,66} \\
\hline & 6 Yaş & 38 & 69,12 & 2626,50 & & & \\
\hline \multirow[b]{2}{*}{ Bilişsel Empati } & 5 Yaş & 104 & 72,25 & 7514,50 & \multirow[b]{2}{*}{1897,50} & \multirow[b]{2}{*}{$-0,37$} & \multirow[b]{2}{*}{0,71} \\
\hline & $6 \mathrm{Yas}$ & 38 & 69,43 & 2638,50 & & & \\
\hline
\end{tabular}

${ }^{* \mathrm{p}}<.05$

Tablo 7'de görüldüğü gibi çocuklar için empati bölümü ölçeğinin alt boyutlarından olan duygusal empati, davranışsal empati'ye ve bilişsel empati bölümlerinin çocukların yaşına göre istatistiksel olarak anlamlı bir farklılığa yol açmadığ belirlenmiştir $\left(\mathrm{U}_{(\mathrm{dye})}=1694,000, \mathrm{z}=-1,395, \mathrm{p}>, 05\right.$; $\left.\mathrm{U}_{(\mathrm{dve})}=1885,500, \mathrm{z}=-, 433, \mathrm{p}>, 05 ; \mathrm{U}_{(\mathrm{be})}=1897,500, \mathrm{z}=-.372, \mathrm{p}>, 05\right)$.

Araştırma kapsamında yer alan annelerin, ebeveynlik tutumlarının yaş değişkenine göre değişip değişmediğine ilişkin ebeveyn tutum ölçeği kullanılarak alınan puanların Kruskal Wallis H testine göre sonuçları Tablo 8'de verilmiştir.

Tablo 8. Ebeveyn tutum ölçeğinden alınan puanların anne yaş değişkenine ilişkin Kruskal Wallis $\mathrm{H}$ testi sonuçlar1

\begin{tabular}{|c|c|c|c|c|c|c|}
\hline Ebeveyn Tutumu & Anne Yaş Grubu & $\mathrm{n}$ & $\begin{array}{c}\text { Sira } \\
\text { ortalamas } 1\end{array}$ & sd & $\mathrm{X}^{2}$ & $\mathrm{p}$ \\
\hline \multirow{4}{*}{ Demokratik } & $20-30$ & 39 & 79,38 & \multirow{4}{*}{3} & \multirow{4}{*}{5,60} & \multirow{4}{*}{0,13} \\
\hline & $31-35$ & 51 & 76,09 & & & \\
\hline & $36-40$ & 40 & 59,78 & & & \\
\hline & $41+$ & 12 & 65,46 & & & \\
\hline \multirow{4}{*}{ Otoriter } & $20-30$ & 39 & 79,81 & \multirow{4}{*}{3} & \multirow{4}{*}{3,01} & \multirow{4}{*}{0,39} \\
\hline & $31-35$ & 51 & 64,83 & & & \\
\hline & $36-40$ & 40 & 71,03 & & & \\
\hline & $41+$ & 12 & 74,42 & & & \\
\hline \multirow{4}{*}{ Aşırı Koruyucu } & $20-30$ & 39 & 74,59 & \multirow{4}{*}{3} & \multirow{4}{*}{1,22} & \multirow{4}{*}{0,74} \\
\hline & $31-35$ & 51 & 69,21 & & & \\
\hline & $36-40$ & 40 & 74,3 & & & \\
\hline & $41+$ & 12 & 61,88 & & & \\
\hline \multirow{4}{*}{ İzin Verici } & $20-30$ & 39 & 69,29 & \multirow{4}{*}{3} & \multirow{4}{*}{0,34} & \multirow{4}{*}{0,95} \\
\hline & $31-35$ & 51 & 71,34 & & & \\
\hline & $36-40$ & 40 & 72,18 & & & \\
\hline & $41+$ & 12 & 77,08 & & & \\
\hline
\end{tabular}

Tablo 8 incelediğinde annelerin ebeveynlik tutum ölçeği alt boyutlarından olan demokratik ebeveyn, otoriter ebeveyn, aşırı koruyucu ebeveyn ve izin verici ebeveyn tutumunun anne yaşı değişkenine 
göre istatistiksel olarak anlamlı farkl1lık göstermediği bulunmuştur $\left(\mathrm{x}_{(\mathrm{de})}^{2}=5,60, \mathrm{sd}=3, \mathrm{p}>, 05 ; \mathrm{x}^{2}{ }_{(\mathrm{oe})}=\right.$ $\left.3,01, \mathrm{sd}=3, \mathrm{p}>, 05 ; \mathrm{x}_{\text {(ake) }}^{2}=1,22, \mathrm{sd}=3, \mathrm{p}>, 05 ; \mathrm{x}_{\text {(ive) }}{ }^{2}=0,34, \mathrm{sd}=3, \mathrm{p}>, 05\right)$.

Araştırmaya katılan annelerin, ebeveynlik tutumlarının anne eğitim düzeyi değişkenine göre değişip değişmediğine ilişkin ebeveyn tutum ölçeği kullanılarak alınan puanların Kruskal Wallis H testine göre sonuçları Tablo 9'da verilmiştir.

Tablo 9. Ebeveyn tutum ölçeğinden alınan puanların anne eğitim düzeyi değişkenine göre Kruskal Wallis H testi sonuçları

\begin{tabular}{|c|c|c|c|c|c|c|}
\hline Ebeveyn Tutumu & Eğitim Durumu & $\mathrm{n}$ & Sira ortalamas1 & $\mathrm{sd}$ & $\mathrm{X}^{2}$ & $\mathrm{p}$ \\
\hline \multirow{6}{*}{ Demokratik } & İlkokul & 24 & 54,96 & \multirow{6}{*}{5} & \multirow{6}{*}{7,17} & \multirow{6}{*}{0,21} \\
\hline & Ortaokul & 12 & 81,29 & & & \\
\hline & Lise & 33 & 66,76 & & & \\
\hline & Ön lisans & 24 & 72,44 & & & \\
\hline & Lisans & 38 & 79,11 & & & \\
\hline & Lisansüstü & 11 & 82,82 & & & \\
\hline \multirow{6}{*}{ Otoriter } & İlkokul & 24 & 68,94 & \multirow{6}{*}{5} & \multirow{6}{*}{6,12} & \multirow{6}{*}{0,29} \\
\hline & Ortaokul & 12 & 88,42 & & & \\
\hline & Lise & 33 & 71,42 & & & \\
\hline & Ön lisans & 24 & 82,9 & & & \\
\hline & Lisans & 38 & 62,22 & & & \\
\hline & Lisansüstü & 11 & 66,05 & & & \\
\hline \multirow{6}{*}{ Aşır1 Koruyucu } & İlkokul & 24 & 85,6 & \multirow{6}{*}{5} & \multirow{6}{*}{11,89} & \multirow{6}{*}{$0,04^{*}$} \\
\hline & Ortaokul & 12 & 90,63 & & & \\
\hline & Lise & 33 & 74,45 & & & \\
\hline & Ön lisans & 24 & 64,56 & & & \\
\hline & Lisans & 38 & 66,39 & & & \\
\hline & Lisansüstü & 11 & 43,77 & & & \\
\hline \multirow{6}{*}{ İzin Verici } & İlkokul & 24 & 65.00 & \multirow{6}{*}{5} & \multirow{6}{*}{2,89} & \multirow{6}{*}{0,72} \\
\hline & Ortaokul & 12 & 82.79 & & & \\
\hline & Ortaöğretim & 33 & 70.50 & & & \\
\hline & Ön lisans & 24 & 64.67 & & & \\
\hline & Lisans & 38 & 74.80 & & & \\
\hline & Lisansüstü & 11 & 79.86 & & & \\
\hline
\end{tabular}

${ }^{* \mathrm{p}}<.05$

Tablo 9 incelediğinde ebeveynlik tutum ölçeği alt boyutlarından olan demokratik ebeveyn, otoriter ebeveyn ve izin verici ebeveyn tutumunun anne eğitim düzeyleri değişkenine göre anlamlı farklılık göstermediği belirlenmiştir $\left(\mathrm{x}_{\text {(de) }}^{2}=7,17, \mathrm{sd}=5, \mathrm{p}>, 05 ; \mathrm{x}_{(\text {(o) }}^{2}=6,12, \mathrm{sd}=6, \mathrm{p}>, 05 ; \mathrm{x}_{\text {(ive) }}^{2}=2,89, \mathrm{sd}=5\right.$, $\mathrm{p}>, 05)$. Ancak ebeveynlik tutum ölçeğinin diğer bir alt boyutu olan aşırı koruyucu ebeveyn tutumu ile anne eğitim düzeyleri arasında istatistiksel olarak anlamlı bir farklılık olduğu saptanmıştır $\left(\mathrm{x}^{2}{ }_{\text {(ake) }}=\right.$ 11,89, sd=5, p<,05). Farklılığın hangi gruptan kaynaklandığını belirlemek için yapılan Mann 
Whitney U testi sonucunda lisansüstü eğitimi olan anneler; ilkokul ve ortaokul mezunu annelerden anlamlı olarak farklılık göstermiştir. Bu farklılık sonucunda ilkokul ve ortaokul mezunu annelerin lisansüstü mezunu olan annelere göre daha koruyucu olduğu sonucuna ulaşılmıştır $(\mathrm{p}<, 05)$.

Araştırmaya katılan annelerin ebeveynlik tutumlarının gelir durumu değişkenine göre farklılık olup olmadığına ilişkin ebeveyn tutum ölçeği kullanılarak alınan puanların Kruskal Wallis H testine göre sonuçları Tablo 10'da verilmiştir.

Tablo 10. Ebeveyn tutum ölçeğinden alınan puanların gelir durumu değişkenine göre Kruskal Wallis $\mathrm{H}$ testi sonuçlar1

\begin{tabular}{|c|c|c|c|c|c|c|}
\hline Ebeveyn Tutumu & Gelir Durumu & $\mathrm{n}$ & Sira ortalamas1 & $\mathrm{sd}$ & $\mathrm{X}^{2}$ & $\mathrm{p}$ \\
\hline \multirow{3}{*}{ Demokratik } & Düşük & 10 & 42,50 & \multirow{3}{*}{2} & \multirow{3}{*}{6,89} & \multirow{3}{*}{$0,03 *$} \\
\hline & Orta & 88 & 70,58 & & & \\
\hline & İyi & 44 & 79,93 & & & \\
\hline \multirow{3}{*}{ Otoriter } & Düşük & 10 & 75,10 & \multirow{3}{*}{2} & \multirow{3}{*}{1,12} & \multirow{3}{*}{0,57} \\
\hline & Orta & 88 & 73,81 & & & \\
\hline & İyi & 44 & 66,07 & & & \\
\hline \multirow{3}{*}{ Aşırı Koruyucu } & Düşük & 10 & 79,10 & \multirow{3}{*}{2} & \multirow{3}{*}{1,06} & \multirow{3}{*}{0,59} \\
\hline & Orta & 88 & 73,03 & & & \\
\hline & İyi & 44 & 66,72 & & & \\
\hline \multirow{3}{*}{ İzin Verici } & Düşük & 10 & 83,20 & \multirow{3}{*}{2} & \multirow{3}{*}{0,99} & \multirow{3}{*}{0,61} \\
\hline & Orta & 88 & 71,50 & & & \\
\hline & İyi & 44 & 68,84 & & & \\
\hline
\end{tabular}

${ }^{* \mathrm{p}}<.05$

Tablo 10 incelendiğinde ebeveynlik tutum ölçeği alt boyutlarından olan otoriter ebeveyn, aşırı koruyucu ebeveyn ve izin verici ebeveyn ile gelir durumu değişkeni arasında anlamlı bir farklılık bulunmamıştır $\left(\mathrm{x}_{(\mathrm{oe})}^{2}=1,12, \mathrm{sd}=2, \mathrm{p}>, 05 ; \mathrm{x}_{\text {(ake) }}=1,06, \mathrm{sd}=2, \mathrm{p}>, 05 ; \mathrm{x}_{\text {(ive) }}^{2}=, 99, \mathrm{sd}=2, \mathrm{p}>, 05\right)$. Ebeveynlik tutum ölçeğinin diğer bir alt boyutu olan demokratik ebeveyn tutumu ile gelir durumu değişkeni arasında gelir durumu iyi olan aileler lehine anlamlı bir farklılığa rastlanmıştır $\left(\mathrm{x}^{2}{ }_{(\mathrm{de})}=6,89\right.$, $\mathrm{sd}=2, \mathrm{p}<, 05)$.

Araştırmaya katılan annelerin ebeveynlik tutumlarının sahip oldukları çocuk sayısı değişkenine göre farklılık olup olmadığına ilişkin ebeveyn tutum ölçeği kullanılarak alınan puanların Kruskal Wallis $\mathrm{H}$ testine göre sonuçları Tablo 11'de verilmiştir.

Tablo 11. Ebeveyn tutum ölçeğinden alınan puanların sahip oldukları çocuk sayısı değişkenine göre Kruskal Wallis $\mathrm{H}$ testi sonuçları

\begin{tabular}{lcccccc}
\hline Ebeveyn Tutumu & Çocuk Sayıs & $\mathrm{n}$ & Sira ortalamas1 & $\mathrm{sd}$ & $\mathrm{X}^{2}$ & $\mathrm{p}$ \\
\hline \multirow{3}{*}{ Demokratik } & 1 & 47 & 76,84 & & & \\
& 2 & 65 & 74,91 & 2 & 5,66 & 0,06 \\
\hline
\end{tabular}




\begin{tabular}{|c|c|c|c|c|c|c|}
\hline Otoriter & $\begin{array}{c}1 \\
2 \\
3+ \\
\end{array}$ & $\begin{array}{l}47 \\
65 \\
30 \\
\end{array}$ & $\begin{array}{l}66,53 \\
74,15 \\
73,55\end{array}$ & 2 & 1,03 & 0,59 \\
\hline Aşırı Koruyucu & $\begin{array}{c}1 \\
2 \\
3+\end{array}$ & $\begin{array}{l}47 \\
65 \\
30\end{array}$ & $\begin{array}{l}69,31 \\
74,66 \\
68,08\end{array}$ & 2 & 0,72 & 0,69 \\
\hline İzin Verici & $\begin{array}{c}1 \\
2 \\
3+\end{array}$ & $\begin{array}{l}47 \\
65 \\
30\end{array}$ & $\begin{array}{l}75,15 \\
71,47 \\
65,85\end{array}$ & 2 & 0,94 & 0,62 \\
\hline
\end{tabular}

$*_{\mathrm{p}}<.05$

Tablo 11 incelendiğinde ebeveynlik tutum ölçeği alt boyutları olan demokratik ebeveyn, otoriter ebeveyn, aşırı koruyucu ebeveyn ve izin verici ebeveyn tutumunun, sahip oldukları çocuk sayısına göre anlamlı bir farklılığa neden olmadığı tespit edilmiştir $\left(\mathrm{x}_{(\mathrm{de})}^{2}=5,66, \mathrm{sd}=2, \mathrm{p}>, 05 ; \mathrm{x}^{2}{ }_{(\mathrm{oe})}=1,03\right.$, $\left.\mathrm{sd}=2, \mathrm{p}>, 05 ; \mathrm{x}_{\text {(ake) }}^{2}=, 72, \mathrm{sd}=2, \mathrm{p}>, 05 ; \mathrm{x}_{\text {(ive) }}^{2}=, 94, \mathrm{sd}=2, \mathrm{p}>, 05\right)$.

Araştırmaya katılan annelerin ebeveynlik tutumlarının; araştırmada yer alan çocuklarının yaş grubu değişkenine göre farklılık olup olmadığına ilişkin ebeveyn tutum ölçeği kullanılarak alınan puanların Kruskal Wallis $\mathrm{H}$ testine göre sonuçları Tablo 12'de verilmiştir.

Tablo 12. Ebeveyn tutum ölçeğinden alınan puanların çocuk yaş grubu değişkenine ilişkin Mann-Whitney $\mathrm{U}$ testi sonuçları

\begin{tabular}{|c|c|c|c|c|c|c|c|}
\hline Ebeveyn Tutumu & Yaş Grubu & $\mathrm{n}$ & Siralar Ortalamas1 & Siralar Toplam1 & $\mathrm{U}$ & Z & $p$ \\
\hline \multirow{2}{*}{ Demokratik } & 5 Yaş & 104 & 72,74 & 7565,00 & \multirow{2}{*}{1847,00} & \multirow{2}{*}{$-0,60$} & \multirow{2}{*}{0,55} \\
\hline & 6 Yaş & 38 & 68,11 & 2588,00 & & & \\
\hline \multirow{2}{*}{ Otoriter } & 5 Yaş & 104 & 72,07 & 7495,00 & \multirow{2}{*}{1917,00} & \multirow{2}{*}{$-0,27$} & \multirow{2}{*}{0,78} \\
\hline & 6 Yaş & 38 & 69,95 & 2658,00 & & & \\
\hline \multirow{2}{*}{ Aşırı Koruyucu } & 5 Yaş & 104 & 72,89 & 7580,50 & \multirow{2}{*}{1831,50} & \multirow{2}{*}{$-0,67$} & \multirow{2}{*}{0,50} \\
\hline & 6 Yaş & 38 & 67,70 & 2572,50 & & & \\
\hline \multirow{2}{*}{ İzin Verici } & 5 Yaş & 104 & 71,35 & 7420,50 & \multirow{2}{*}{1960,50} & \multirow{2}{*}{$-0,07$} & \multirow{2}{*}{0,94} \\
\hline & 6 Yaş & 38 & 71,91 & 2732,50 & & & \\
\hline
\end{tabular}

${ }^{* \mathrm{p}}<.05$

Tablo 12'de görüldüğü gibi ebeveynlik tutum ölçeğinin alt boyutları olan demokratik ebeveyn, otoriter ebeveyn, aşırı koruyucu ebeveyn ve izin verici ebeveyn tutumunun araştırmaya katılan çocuklarının yaş grubuna göre anlamlı bir farklılığa neden olmadığ1 tespit edilmiştir $\left(\mathrm{U}_{(\mathrm{de})}=\right.$ 1874.000, $\mathrm{z}=-, 596, \mathrm{p}>, 05 ; \mathrm{U}_{(\mathrm{oe})}=1917.000, \mathrm{z:-}, 273, \mathrm{p}>, 05 ; \mathrm{U}_{(\mathrm{ake})}=1831.500, \mathrm{z}=-, 273, \mathrm{p}>, 05$; $\left.\mathrm{U}_{(\mathrm{ive})}=1960.500, \mathrm{z}=-, 072, \mathrm{p}>, 05\right)$.

Araştırmaya katılan annelerin ebeveynlik tutumları ve çocuklarının empati düzeyleri arasındaki ilişkilerin belirlenmesi amacıyla Spearman korelasyon analizinden yararlanılarak elde edilen bulgular Tablo 13'de gösterilmiştir. 
Tablo 13. Anne ebeveyn tutumu ile çocuklarının empati bölümleri arsındaki ilişkiyi gösteren Spearman Korelasyon analizi sonuçları

\begin{tabular}{|c|c|c|c|c|c|}
\hline Ebeveyn Tutumu & & Duygusal Empati & Davranısssal Empati & Bilişsel Empati & Genel Empati \\
\hline \multirow{3}{*}{ Demokratik } & $\mathrm{r}$ & $-0,221^{* *}$ & $-0,105$ & $-0,13$ & $-0,19^{*}$ \\
\hline & $\mathrm{p}$ & 0,008 & 0,21 & 0,12 & 0,024 \\
\hline & $\mathrm{n}$ & 142 & 142 & 142 & 142 \\
\hline \multirow{3}{*}{ Otoriter } & $\mathrm{r}$ & $0,234^{* *}$ & $0,271^{* *}$ & 0,13 & $0,305^{* *}$ \\
\hline & $\mathrm{p}$ & 0,005 & 0,001 & 0,13 & 0,00 \\
\hline & $\mathrm{n}$ & 142 & 142 & 142 & 142 \\
\hline \multirow{3}{*}{ Aşırı Koruyucu } & $\mathrm{r}$ & 0,02 & $-0,08$ & 0,09 & 0,01 \\
\hline & $\mathrm{p}$ & 0,833 & 0,37 & 0,29 & 0,90 \\
\hline & $\mathrm{n}$ & 142 & 142 & 142 & 142 \\
\hline \multirow{3}{*}{ İzin Verici } & $\mathrm{r}$ & $0,184^{*}$ & 0,002 & 0,08 & 0,12 \\
\hline & $\mathrm{p}$ & 0,03 & 0,98 & 0,33 & 0,17 \\
\hline & $\mathrm{n}$ & 142 & 142 & 142 & 142 \\
\hline
\end{tabular}

$* * \mathrm{p}<.01$

Çocuklar için empati bölümü ölçeğinin puanlaması ters olduğu için, puan sıfira yaklaştıkça empatik düzeyin arttığı düşünüldüğünden, tabloda negatif görülen ilişkiler pozitif, pozitif görülen ilişkiler negatif olarak yorumlanmıştır. Bu nedenle Tablo 13 incelendiğinde demokratik ebeveyn tutumu ile duygusal empati arasında pozitif yönlü bir ilişki bulunmaktadır $(\mathrm{r}=-, 221, \mathrm{p}<.01)$. Otoriter ebeveyn tutumu ile duygusal empati ve davranışsal empati arasında ise negatif bir ilişki bulunmaktadır $(r=, 234, p<.01 ; r=, 271, p<.01)$. İzin verici ebeveyn tutumu ile duygusal empati arasinda da negatif yönlü ilişki olduğu görülmüştür $(\mathrm{r}=, 184, \mathrm{p}<.05)$. Aşırı koruyucu ebeveyn tutumu ile ise duygusal, davranışsal ve bilişsel empati bölümü arasında herhangi bir ilişki saptanmamışırır (r=,02, p> $>05$; r= -,08, p>,05; r=,09, p>,05). Tablo 13'deki bilgiler doğrultusunda ebeveynlik tutumları ve genel empati durumları arasında anlamlı ilişkiler bulunduğu tespit edilmiştir. Demokratik ebeveyne sahip çocuklar ile genel empati beceri arasında pozitif yönlü anlamlı ilişki olduğu, otoriter ebeveyne sahip çocuklar ile genel empati beceri arasında negatif yönlü anlamlı ilişki olduğu görülmüştür $(\mathrm{r}=-, 19$, $\mathrm{p}<, 05 ; \mathrm{r}=, 305, \mathrm{p}<, 01)$. Aşırı koruyucu ebeveyn ve izin verici ebeveyne sahip çocuklar ile genel empati durumlanı arasında ise istatistiksel açıdan anlamlı ilişkiler bulunmamıştır $(\mathrm{r}=, 01, \mathrm{p}>, 05$; $r=, 12, p>, 05)$.

\section{TARTIŞMA}

Bu çalışmada okul öncesi çocukların empati bölümleri ile annelerinin ebeveyn tutumları arasındaki ilişkinin incelenmesi amaçlanmıştır. Araştırma kapsamında elde edilen bulgular ışığında, çocukların duygusal empati bölümünün, anne yaşı, baba yaşı, baba eğitim durumu, gelir durumu, kardeş sayısı ve çocuğun yaşına göre; davranışsal empati bölümünün, anne yaşı, baba yaşı, baba eğitim durumu, kardeş sayısı ve çocuğun yaşına göre; bilişsel empati bölümünün ise anne yaşı, baba yaşı, baba eğitim durumu, gelir durumu, kardeş sayısı ve çocuğun yaşına göre istatistiksel olarak anlamlı bir farklılık 
göstermediği belirlenmiştir. Özer'in (2016), empati eğitim programının anaokulu çocuklarının empatik ve prososyal becerilerine etkisini incelediği çalışmasında, anne-baba yaşı ile çocukların empatik becerileri arasında anlamlı bir ilişki olmadığı sonucuna ulaşılmıştır. Ayrıca bir diğer çalışma olan Taner Derman (2013) tarafindan yapılan araştırmada da, empati beceri düzeylerinin çocuğun anne-baba yaşı ve ailedeki çocuk sayısı değişkenleri ile bir ilişkisinin olmadığı saptanmıştır. Bu sonuçlar bu araştırma sonuçlarıyla örtüşmektedir.

Çocukların duygusal ve bilişsel empati bölümünün anne eğitim durumuna göre lisans mezunu anneler lehine; davranışsal empati bölümünün ise ailenin gelir durumuna göre gelir durumu iyi olanlar lehine istatistiksel olarak anlamlı bir farklılık gösterdiği belirlenmiştir. Lisans mezunu annelerin çocuklarının duygusal ve bilişsel empati bölümlerinde, gelir durumu iyi olan ailelerin çocuklarının ise davranışsal empati bölümlerinde daha becerikli oldukları görülmektedir. Taner Derman'ın (2013) yaptığı çalışmada da çocukların empati düzeylerinin anne eğitim düzeyine göre farklılaştığı belirlenmiştir. Köse'nin (2019) çalışmasında da annelerin eğitim düzeylerinin çocukların empati düzeyleri üzerinde anlamlı farklılıklar oluşturduğu tespit edilmiş ve bu farklıllğın okur yazar annelerin aleyhine olduğu belirtilmiştir. Aslan (2018) tarafindan yürütülen, çocukların empati becerilerinin anne çocuk ilişkisi açısından incelendiği çalışmada ailenin sosyoekonomik durumu ile çocukların empati becerileri arasında anlamlı farklılık olduğu tespit edilmiştir. Bu farklılığın üst gelire sahip ailelerin alt gelir grubundakilere göre anlamlı şekilde yüksek olduğu belirtilmiştir. Literatürdeki bu çalışmalar da bu çalışmanın bulgularını destekler niteliktedir. Çalışmada elde edilen bu sonucun, eğitim düzeyi ve gelir durumu yüksek olan annelerin çocuklarının duygularına daha duyarl1, onların duygu ve düşüncelerini anlayabilme becerisine sahip oldukları, çocuklarıyla duyguları hakkında daha fazla konuştukları, kısaca empatik davranışlar sergiledikleri için çocuklarına örnek olmalarından kaynaklandığı düşünülmektedir.

Araştırmada, ebeveyn tutum ölçeğinin alt boyutları olan demokratik tutumun anne yaşı ile eğitim durumuna, çocuk sayısına ve çocuğun yaşına; otoriter tutumun anne yaşı ile eğitim durumuna, gelir durumuna, çocuk sayısına ve çocuğun yaşına; aşırı koruyucu tutumun anne yaşına, gelir durumuna, çocuk sayısına, çocuğun yaşına; izin verici tutumun anne yaşı ile eğitim durumuna, gelir durumuna, çocuk sayısına, çocuğun yaşına göre istatistiksel açıdan anlamlı farklılığa neden olmadığı tespit edilmiştir. Literatüre bakıldığında; Sak, Şahin Sak, Atli ve Şahin (2015), demokratik ve otoriter ebeveyn tutumunun sahip olunan çocuk sayısından etkilendiğini, izin verici ve aşırı koruyucu ebeveyn tutumunun ise çocuk sayısı değişkeninden etkilenmediği sonucuna ulaşmışlardır. Özyürek ve Tezel Şahin (2005), 5-6 yaş grubunda çocuğu olan ebeveynlerin anne ve baba tutumlarının, ebeveynlerin yaşlarından etkilenmediğini saptamıştır. Yavuzer (2001) tarafindan yapılan çalışmada, 
anne yaşının, çocuk yetiştirme ile ilgili boyutların hiçbirinde anlamlı bir farklılık yaratmadığı tespit edilmiştir. Alabay (2017), demokratik tutumun 48-72 aylık çocuğu olan ebeveynlerin yaşına göre farklılaştı̆̆ını, fakat otoriter, aşırı koruyucu ve izin verici tutumların farklılaşmadığını saptamıştır.

Bu çalışmada demokratik tutumun ailenin gelir durumu bakımından iyi olanlar lehine; aşırı koruyucu tutumun anne eğitim durumu bakımından ilkokul ve ortaokul mezunu anneler lehine istatistiksel olarak anlamlı farklılık gösterdiği bulunmuştur. Kısaca, gelir durumu iyi olan annelerin daha demokratik, ilkokul-ortaokul mezunu olan annelerin ise daha koruyucu tutuma sahip olduklar1 belirlenmiştir. Özyürek ve Tezel Şahin (2005), üniversite mezunu olan anne ve babaların aşırı koruyuculuk tutumunun daha düşük olduğunu, anne-babaların otoriter ve aşırı koruyuculuk tutumlarının ise öğrenim düzeyleri arttıkça azaldığını belirlemişlerdir. Aydoğdu ve Dilekmen (2016), ebeveyn eğitim durumları ile demokratik ebeveyn tutumu ve aşırı koruyucu ebeveyn tutumu arasında anlamlı farklılık olduğunu; ön lisans mezunu annelerin ortaokul mezunu annelerden daha demokratik olduğunu, ortaokul mezunu annelerin ise lisans ve lisansüstü mezunu olan ebeveynlere göre daha aşırı koruyuculuk gösterdiklerini tespit etmişlerdir. Yılmaz (2004), olanakların kısıtlı olduğu kesimlerde, ekonomik zorlukların anne babaların çocuklara olan davranış ve disiplin tutumunu olumsuz yönde etkilediği ve ebeveynlerin çocuklara karşı daha olumsuz yaklaştığı; olanakların yüksek olduğu ailelerde ise ebeveynlerin çocuklara daha tahammüllü olup olumlu yaklaştıklarını ifade etmiştir. Ayyıldız (2005), sosyoekonomik yönden üst düzeyde olan ebeveynlerin alt düzeydekilere göre, otoriteye daha az değer verdiklerini; demokratik, meraklı, yaratıcı, başarılı ve sorun çözücü olmayı daha fazla önemsedikleri; düşük sosyoekonomik düzeydeki annelerin ise çocuklarına karşı daha sert davranabildiğini belirtmiştir. Eroğlu (2014), 0-6 yaş arası çocuğu olan ailelerin gelir düzeyi düştükçe çocuklarına karşı koruyuculuklarının artmasına karşın, ailelerin gelir seviyesi arttıkça çocuklarına karşı daha demokratik ve eşitlikçi davrandıklarını belirtmiştir. Özyürek (2004), kırsalda çiftçilikle uğraşan babaların çocuklarına karşı tutumlarının memur olan babalara göre daha koruyucu; serbest meslek yapan, memur ve işçi olan babalara göre daha katı/sert disiplinli olduğu; kentte doktorluk, avukatlık ve öğretmenlik gibi profesyonel mesleği olan babaların tutumlarının diğer mesleklere sahip olanlara göre yani daha iyi gelir düzeyine sahip olan ailelerin ise daha az koruyucu ve katı disiplinli tutuma sahip oldukları bulgusuna ulaşmıştır. Bu çalışmada ilkokul ve ortaokul mezunu annelerin, aşırı koruyucu tutuma sahip olduklarının belirlenmesinin nedeninin, kendi ebeveynlerinden gördükleri gibi davranmalarından, geleneksel Türk toplumunda sıklıkla görülen aşırı koruyucu tutumu devam ettirmelerinden ve yeteri kadar eğitim almadıkları için çocuk yetiştirme hakkında gerekli bilgiye sahip olmamalarından kaynaklandığı düşünülmektedir. Ayrıca, ailenin ekonomik gelir düzeyleri arttıkça, hayatlarında maddi açıdan sıkıntı yaşama düzeyleri azaldığ1 için daha az stresli ve daha az sinirli olmaları dolayısıyla ekonomik açıdan rahat ebeveynlerin 
çocukların ilgi ve isteklerine daha duyarlı ve uygun dönütler vererek daha demokratik tutumu benimsedikleri düşünülmektedir.

Araştırma bulgularına göre, çocukların empati bölümleri ile annelerinin ebeveyn tutumları arasındaki ilişki incelendiğinde; demokratik ebeveyn tutumu ile duygusal empati ve genel empati arasında pozitif yönde anlamlı ilişki; otoriter ebeveyn tutumu ile duygusal, davranışsal ve genel empati arasında negatif yönde; izin verici tutum ile duygusal empati arasında negatif yönde anlamlı ilişki olduğu belirlenmiştir. Diğer yandan, demokratik tutum ile davranışsal ve bilişsel empati; otoriter tutum ile bilişsel empati; aşırı koruyucu tutum ile duygusal, davranışsal, bilişsel ve genel empati; izin verici tutum ile davranışsal, bilişsel ve genel empati arasında istatistiksel açıdan anlamlı ilişki bulunmamıştır. Literatürdeki çalışmalar incelendiğinde de, otoriter olmayan annelerin çocuklarının, duygusal ve bilişsel empati düzeylerinin, otoriter annelerden daha yüksek olduğu görülmüştür (Cotton, 2001). Benzer şekilde Pontania ve Salim (2019) tarafindan yürütülen araştırmada da otoriter ebeveynlik tutumu ile çocukların empatisi arasında negatif ilişki olduğunu saptanmıştır. Parsak (2015), okul öncesi dönem çocukları üzerinde yaptı̆̆1 araştırmasında, çocukların empati düzeyleri ile ebeveyn tutumları arasında anlamlı bir ilişki olduğunu tespit etmiştir. Yürütülen araştırmada ebeveynlerin otoriter tutumu arttıkça empatik olma durumunun azaldığ1 ve ebeveynlerin demokratik tutumu arttıkça çocuklarının empatik olma düzeylerinin arttı̆̆ görülmektedir. Bibi, Chaudhry, Awan ve Tariq’e (2013) göre, otoriter ebeveyn tutumu, çocukların karşı katı ve engelleme eğiliminde olmalarına sebep olmaktadır. Bu eğilim ise çocuk için baskı unsuru olmakta ve çocuğun empati becerisinin azalmasına neden olmaktadır. Bütün bu bilgiler 1şı̆̆ında, çocuklar doğduğu andan itibaren en çok anne ve babalarıly zaman geçirmektedir ve yine rol model olarak en yakınlarında bulunan anne ve babalarını örnek almaktadır. Demokratik tutuma sahip ailelerin, çocuklarını anlama ve onlara empati kurma durumları diğer ebeveyn tutumlarına göre en üst düzeydedir. Bu ortamda büyüyen çocukların, anne ve babalarını örnek alarak daha empatik olma eğiliminde olabileceği düşünülmektedir. Diğer taraftan çocuğun ilgi ve ihtiyaçlarını bastıran ve empati kurma seviyesi oldukça düşün olan otoriter ebeveyne sahip çocukların da yine ailesinden gördüğü şekilde empatik olmayan davranışları örnek alarak bu doğrultuda davranışlar göstermiş olabilecekleri düşünülmektedir.

\section{SONUÇ VE ÖNERİLER}

Duygusal, davranışsal ve bilişsel empati bölümleri, anne-baba yaşına, çocuğun yaşına ve kardeş sayısına göre değişmemektedir. Duygusal ve bilişsel empati bölümünün anne eğitim durumuna ve davranışsal empati bölümünün ailenin gelir durumuna göre farklılaştı̆̆1 belirlenmiştir. Lisans mezunu annelerin çocuklarının duygusal ve bilişsel empati bölümlerinde, gelir durumu iyi olan 
ailelerin çocuklarının ise davranışsal empati bölümlerinde daha becerikli oldukları anlaşılmıştır. Gelir durumu iyi olan annelerin daha demokratik, ilkokul-ortaokul mezunu olan annelerin ise daha koruyucu tutuma sahip oldukları belirlenmiştir. Annenin demokratik tutumu arttıkça ise duygusal empati, genel empati düzeyinin arttığı; otoriter tutumu arttıkça duygusal, davranışsal ve genel empati düzeyinin düştüğü; izin verici tutumu arttıkça ise duygusal empati düzeyinin düştüğü görülmüştür.

Bu sonuçlar 1şı̆̆ında şu öneriler geliştirilmiştir:

Duygusal ve bilişsel empati düzeyinin, anne eğitim düzeyine göre arttı̆̆1 düşünüldügünnde, özellikle eğitim düzeyi düşük olan annelere yönelik empatinin önemi, çocuk gelissimi üzerindeki etkileri konusunda eğitim seminerleri düzenlenmelidir.

Demokratik tutumun ailenin gelir durumuna göre değiştiği düşünüldüğünde, özellikle gelir durumu düşük olan ailelere, ebeveyn tutumlarının önemi, çocuk gelişimi üzerindeki etkileri konusunda eğitimler verilebilir.

Genel empati düzeyi ile otoriter tutum arasında negatif ilişki olduğu düşünüldüğünde, ailelere empatinin önemine yönelik eğitimler verilerek, ailelerin tutumlarının daha demokratik olması sağlanabilir.

Bu çalışmanın bulguları 5-6 yaş grubu çocuklar ve annelerinden elde edilmiştir. Bu çalışma 5-6 yaş çocuklarla sınırlı olduğu için, ileride benzer nitelikli çalışmalar farklı yaş grupları ile özellikle de 5 yaş altındaki çocuklarla yapılabilir. Literatüre bakıldığında küçük yaş grubundaki çocukların empatik becerilerinin ölçülmesi konusunda yeterince kaynak olmadığı görülmektedir. Gelecekte yapılacak çalışmalarla kendi kültürümüze uygun olarak çocukların empati becerisini ölçmeye yönelik ölçekler hazırlanarak alana kazandırılabilir.

\section{KAYNAKÇA}

Afat, N. (2013). Çocuklarda üstün zekânın yordayıcı olarak ebeveyn tutumları. Hasan Ali Yücel Eğitim Fakültesi Dergisi, 20 (1), 155-168.

Akbaş, B. ve Temiz, G. (2015). 60-66 aylık çocukların empati beceri düzeylerinin anne empati beceri düzeyi açısından incelenmesi. Trakya Üniversitesi Ë̆itim Fakültesi Dergisi, 5 (2), 106-112.

Alabay, E. (2017). Okul öncesi dönem çocuğu olan ebeveynlerin ebeveynlik tutumlarının incelenmesi. Erken Çocukluk Çallşmalar Dergisi, 1 (2), 156-174. 
Alisinanoğlu, F. (2003). Çocukların denetim odağı ile algıladıkları anne tutumları arasındaki ilişkinin incelenmesi (çocukların denetim odağı ile anne tutumları). Türk Ë̆itim Bilimleri Dergisi, 1 (1), $1-14$.

Aslan, N. (2018). 60-72 aylık çocukların empati becerilerinin anne çocuk ilişkisi açısından incelenmesi, (Yayımlanmamış Yüksek Lisans Tezi), Marmara Üniversitesi Eğitim Bilimleri Enstitüsü, İstanbul.

Atabey, D. (2017). Anasınıfına devam eden çocukların annelerinin anne tutumlarının incelenmesi (Çorum ili örneği). Hitit Üniversitesi Sosyal Bilimler Enstitüsü Dergisi, 10 (1), 145-167.

Axinn, W.A. \& Thornton, A. (1993). Mothers, children, and cohabitation: the intergenerational effects of attitudes and behavior. American Sociological Review, 58 (2), 233-246.

Aydoğdu, F. ve Dilekmen, M. (2016). Ebeveyn tutumlarının çeşitli değişkenler açısından değerlendirilmesi. Bayburt Eğitim Fakültesi Dergisi, 11 (2), 569- 585.

Ayyıldız, T. (2005). Zonguldak il merkezinde 0-6 yaş çocuğu olan annelerin çocuk yetiştirme tutumları. (Yayımlanmamış Yüksek Lisans Tezi), Zonguldak Karaelmas Üniversitesi, Sağlık Bilimleri Enstitüsü, Zonguldak.

Barrett-Lennard, G. T. (1981). The empathy cycle: Refinement of a nuclear concept. Journal of Counseling Psychology, 28 (2), 91-100.

Baumrind, D. (1966). Effects of authoritative parental control on child behavior. Child Development. $37(4), 887$.

Baumrind, D. (1971). Current patterns of parental authority. Developmental Psychology, 4 (1), 1-103.

Bedge, Z. ve Özyürek, A. (2016). Öğretmen ve anne-baba tutumlarının okul öncesi dönem çocuklarının problem çözme becerilerine etkisi. Amasya Üniversitesi Eğitim Fakültesi Dergisi, 5 (1), 204-232.

Bibi, F., Chaudhry, A. G., Awan, E. A., \& Tariq, B. (2013). Contribution of parenting style in life domain of children. IOSR Journal of Humanities and Social Science (IOSR-JHSS), 12 (2), 91-95.

Büyüköztürk, Ş., Kılıç Çakmak, E., Akgün, Ö. E., Karadeniz, Ş. ve Demirel F. (2018). Bilimsel araștırma yöntemleri (24. Baskı). Ankara: Pegem Akademi Yayıncilı.

Cotton, K. (2001). Developing empathy in children and youth. School Improvement Research Series Close Up \#13. https://educationnorthwest.org/sites/default/files/developing-empathy-inchildren-and-youth.pdf, (Retrieved from: 05.07.2019).

Çetinkaya, B. (2018). Ruhsal açıdan sağhkh aile sağhlkh çocuk (6. Baskı). Ankara: Pegem Akademi.

Damon, W. (1988). The moral child: Nurturing children's natural moral growth. New York: The Free Press.

Dinç Altun, Z., Değerli, F. İ., Çıkrıkçı, N. ve Kınık, Ö. (2018). Çocuklar için Empati Bölümü Ölçeğinin Türkçe'ye uyarlanması. Mehmet Akif Ersoy Üniversitesi Eğitim Fakültesi Dergisi, 45, 153-168. doi: 10.21764/maeuefd.309234 
Dökmen, Ü. (2014). Sanatta ve günlük yaşamda iletişim çatışmalar ve empati (52.basım). İstanbul: Remzi Kitapevi.

Dönmezer, İ. (2001). Ailede iletişim ve etkileşim (3. Baskı). İstanbul: Sistem Yayınc1lık.

Durmuşoğlu Saltalı, N. ve Arslan, E. (2012). Ebeveyn tutumlarının anasınıfına devam eden çocukların sosyal yetkinlik ve içe dönüklük davranışını yordaması. İlköğretim Online, 11 (3), 729-737.

Efe Azkeskin, K., Güven, G., Güral, M. ve Sezer, T. (2013). Parenting styles: Parents with 5-6 year old children. Journal of Educational and Instructional Studies in the World, 3 (1), 74-82.

Eisenberg, N. \& Strayer J. (1987). Empathy and its development. New York: Cambridge University Press.

Emery, E. J. (1987). Empathy: Psychoanalytic and client centered. American Psychologist, 42 (5), 513515.

Eroğlu, M. (2014). 0-6 yaş çocuğa sahip anne babaların sosyo-ekonomik durumlarının ve benlik saygılarının çocuk yetiştirme tutumlarına etkisi. (Yayımlanmamış Yüksek Lisans Tezi), Toros Üniversitesi, Sosyal Bilimler Enstitüsü, Mersin

Gallese, V. (2003). The roots of empathy: The shared manifold hypothesis and the neural basis of intersubjectivity, Psychopathology, 36, 171-180.

Gladstein, G.A., \& Feldstein, J.C. (1983). Using film to increase counselor empathic experiences. Counselor Education and Supervision, 23 (2), 125-131.

Gürtunca, A. (2013). Çocuklar ve ergenler içim empati ölçeği Türkiye geçerlik ve güvenirlik çalışması, (Yayımlanmamış Yüksek Lisans Tezi), Arel Üniversitesi Sosyal Bilimler Enstitüsü, İstanbul.

Grusec, J. E. \& Danyliuk, T. (2014). Parents' attitudes and beliefs: Their impact on children's development. In: Tremblay RE, Boivin M, Peters RDeV, eds. Tremblay RE, topic ed. Encyclopedia on Early Childhood Development [online]. http://www.childencyclopedia.com/parenting-skills/according-experts/parents-attitudes-and-beliefs-theirimpact-childrens-development.

Hoffman M.L. (1987). The contribution of empathy to justice and moral judgment. In Empathy and Its Development (eds. N. Eisenberg ve J. Strayer), p: 47-80, New York: Cambridge University Press.

İkiz, S. ve Öztürk Samur, A. (2016). Okul öncesi dönem çocuklarında fiziksel ve ilişkisel saldırganlığın ebeveyn tutumları açısından incelenmesi. Mustafa Kemal Üniversitesi Sosyal Bilimler Enstitüiü Dergisi, 13 (35), 159-175.

Kahraman, H. (2007). Empatik beceri eğitiminin okul öncesi dönemdeki çocukların empatik becerilerine ve sorun davranışlarına etkisi. (Yayımlanmamış Yüksek Lisans Tezi), Mersin Üniversitesi, Sosyal Bilimler Enstitüsü, Mersin.

Kalayc1, Ș. (2010). SPSS Uygulamal çok değişkenli istatistik teknikleri, Ankara: Pegem Akademi. 
Karabulut Demir, E. ve Şendil, G. (2008). Ebeveyn tutum ölçeği (ETÖ), Türk Psikoloji Yą̧lar, 11 (21), 15-25.

Karasar, N. (2013). Bilimsel araştırma yöntemi (25. Basım). Ankara: Nobel Yayın Dağıtım.

Kaya, A., Bozaslan, H. ve Genç, G. (2012). Üniversite öğrencilerinin anne-baba tutumlarının problem çözme becerilerine, sosyal kaygı düzeylerine ve akademik başarılarına etkisi. Dicle Üniversitesi Ziya Gökalp Eğitim Fakültesi Dergisi, 18, 208-225.

Köksal, A. (2005). Erken çocukluk döneminde empati gelişimi. Coluk Çocuk Dergisi, 51, 12-13.

Köse, D. (2019) Anne baba tutumlarının, çocukta benlik saygısı ve empati gelişimi ile ilişkisinin incelenmesi, (Yayımlanmamış Yüksek Lisans Tezi), İstanbul Aydın Üniversitesi Sosyal Bilimler Enstitüsü, İstanbul.

Maccoby, E. E. \& Martin, J. A. (1983). Socialization in the contex of the family: Parent-child interaction. In P. H. Mussen (Series Ed.) ve E. M. Hetherington (Vol. Ed.), Handbook of child psychology: Vol. 4. Socialization, personality, and social developmet (4th ed., pp.1-101) Newyork: Wiley Publishing.

Mete, B. (2005). Lise son sınıf öğrencilerinin empatik becerileri ile aile işlevleri arasındaki ilişkinin çeşitli değişkenler açısından incelenmesi, (Yayımlanmamış Yüksek Lisans Tezi), Dokuz Eylül Üniversitesi Eğitim Bilimleri Enstitüsü, İzmir.

Önder, A. (2015). Çocukta empati gelişimi. (Edt. Y. Kabapınar), Empatiyle gelismek empatiyi gelistirmek: Cocuk ve empati. Ankara: Pegem Akademi.

Önder, A. ve Gülay, H. (2007). Annelerin kabul red düzeyi ile çocuklarının empati becerisi arasındaki ilisskinin incelenmesi. Pamukkeale Üniversitesi Ë̆itim Fakültesi Dergisi, 2 (22), 23-30.

Özdal, F. (2003). İlköğretim dört ve beşinci sınıfa devam eden, anne-babası ile yaşayan ve baba yoksunu olan çocukların kaygı düzeylerinin incelenmesi. (Yayımlanmamış Yüksek Lisans Tezi), Ankara Üniversitesi Fen Bilimleri Enstitüsü, Ankara.

Özdemir, O., Güzel Özdemir, P., Kadak, M. ve Nasıroğlu, S. (2012). Kişilik gelişimi. Psikìyatride Güncel Yaklassımlar, 4 (4), 566-589.

Özer, G. (2016). Empati eğitim programının anaokulu çocuklarının empatik ve prososyal becerilerine etkisinin incelenmesi, (Yayımlanmamış Doktora Tezi), Hacettepe Üniversitesi, Eğitim Bilimleri Enstitüsü, Ankara.

Özyürek, A. (2004). Kırsal bölge ve şehir merkezinde yaşayan 5-6 yaş grubu çocuğa sahip annebabaların çocuk yetiştirme tutumlarının incelenmesi. (Yayımlanmamış Yüksek Lisans Tezi), Gazi Üniversitesi Eğitim Bilimleri Enstitüsü, Ankara.

Özyürek, A. ve Tezel Şahin, F. (2005). 5-6 Yaş grubunda çocuğu olan ebeveynlerin tutumlarının incelenmesi, Gaæi Üniversitesi Gaæ̧i Eğitim Fakültesi Dergisi, 25 (2), 19-34.

Parsak, B. (2015). Ebeveyn tutumları ile okul öncesi dönem çocuklarının davranış problemleri arasındaki ilişkide çocukların empati ve sosyal beceri düzeylerinin rolü. (Yayımlanmamış Yüksek Lisans Tezi), Adnan Menderes Üniversitesi Sosyal Bilimler Enstitüsü, Aydın. 
Pontania, A. R., \& Salim R. M. A. (2019). The relation of child's empathy and parents' prejudice: The mediating role of parenting style. Humaniora, 10 (2), 105-112. https://doi.org/10.21512/humaniora.v10i2.5476

Ridley, C. A., Vaughn, S. R., \& Wittman, S. K. (1982). Developing empathic skills: A model for preschool children. Child Study Journal, 12 (2), 89-97.

Rubin, K. H. \& Burgess, K. (2002). Parents of aggressive and withdrawn children. In M. Bornstein (Ed.), Handbook of Parenting. (2nd Edition). Volume 1, 383-418. Hillsdale, N. J.: Lawrence Erlbaum Associates. https://www.researchgate.net/publication/232567285_Parents_of_aggressive_and_with drawn_children, (Retrieved from: 05.07.2019).

Sak, R., Şahin Sak, İ.T., Atli, S. ve Şahin, B. K. (2015). Okul öncesi dönem: Anne baba tutumları. Mersin Üniversitesi Ë̈itim Fakültesi Dergisi, 11 (5), 972-991.

Staub, E. (1990). Commentary on part I. In Empathy and its development (Eds. N. Eisenberg \& J. Strayer), (Cambridge studies in social and emotional development. Empathy and its development (p. 103-115). Cambridge: Cambridge University Press. https://books.google.com.tr/books?id=PVQ4AAAAIAAJ\&printsec $=$ frontcover\&hl=tr \&source $=$ gbs_ge_summary_r\&cad $=0 \#_{\mathrm{v}}=$ onepage\&q $=$ staub\&f $=$ false, (Retrieved from: 05.07.2019).

Sümer, N., Gündoğdu Aktürk, E. ve Helvacı, E. (2010). Anne-baba tutum ve davranışlarının psikolojik etkileri: Türkiye'de yapılan çalışmalara toplu bakış. Türk Psikoloji Yąılar,13 (25), 42-59.

Şahin, S. ve Karaaslan, T. (2006). Üç-altı yaş grubu çocukların sosyal beceri düzeylerinin incelenmesi, Cocuk Gelişimi ve Eğitimi Dergisi, 1 (2), 74-80.

Şahin, D., Ocak Karabay, Ş. ve Demir, T. (2017). 5 yaş çocuklarının sosyal duygusal uyumları ile ebeveynlerinin tutumları arasındaki ilişki. Disiplinlerarası Ë̆itim Araștırmaları Dergisi, 1 (2) , 1 14.

Şanlı, D. ve Öztürk, C. (2012). Annelerin çocuk yetiştirme tutumlarını etkileyen etmenlerin incelenmesi. Dokuг Eylül Üniversitesi Buca Eğitim Fakültesi Dergisi, 32, 31-48.

Şanl, D ve Öztürk, C. (2015). Anne babaların çocuk yetiştirme tutumları ve tutumlar üzerine kültürün etkisi. Dokuz Eylül Üniversitesi Hemsirelik Fakültesi Elektronik Dergisi, 8 (4), 240-246.

Tarhan, N. (2013). Sevmek, değer vermek ve empatinin basamaklar1, http:/ /www.yazete.com/yazilar/prof-dr-nevzat-tarhan/sevmek-deger-vermek-veempatinin-basamaklari/477346/. (Erişim Tarihi: 02 Ocak 2019).

Taner Derman, M. (2013). Çocukların empati beceri düzeylerinin ailesel etmenlere göre belirlenmesi, International Journal of Social Science, 6 (1), 1365-1382.

Tatlı, S., Selimoğlu, H. ve Bademci, D. (2012). Çocukları okul öncesi eğitime devam eden annelerin aile hayatı ve çocuk yetiştirme tutumlarının incelenmesi. Bingöl Üniversitesi Sosyal Bilimler Enstitüsü Dergisi, 2 (3): 101-114.

Temel, D. ve Türkoğlu, B. (2019). Yerleşim yerlerine göre anne baba tutumlarının okul öncesi çocukların sosyal becerilerine etkisi. Gą̧i Üniversitesi Ë̆itim Fakültesi Dergisi, 39 (2), 843-871. 
Tezel Şahin, F. ve Özyürek, A. (2008). 5-6 yaş grubu çocuğa sahip ebeveynlerin demografik özelliklerinin çocuk yetiştirme tutumlarına etkisinin incelenmesi. Türk Eğitim Bilimleri Dergisi, $6(3), 395-414$.

Toksöz, E. (2010). İlköğretim ikinci kademe öğrencilerinin zorbalık eğilimleri ve aile tutumu arasındaki ilişki üzerine bir araştırma: Eskişehir ili örneği. (Yayımlanmamış Yüksek Lisans Tezi), Yeditepe Üniversitesi Sosyal Bilimler Enstitüsü. İstanbul.

Türk Dil Kurumu (2012). Türkģe söఇlïk. Türk Dil Kurumu, www.tdk.gov.tr. (Erişim tarihi: 20 May1s 2019).

Vischer, R. (1873). Ueber das optische formgefübl. Ein beitrag zur aesthetik. Leipzig: Credner. https:/ / books.google.com.tr/books?hl=tr\&lr=\&id=2KcDAAAAYAAJ\&oi=fnd\&pg=P A1\&dq=Robert + Vischer $+(1873)+$ \&ots=b00FZdE9Va\&sig=041ILqpARfzIajDhHCu3U $\mathrm{x} 60 \mathrm{~W}$ tg\&redir_esc $=\mathrm{y} \#_{\mathrm{v}}=$ onepage $\& \mathrm{q}=$ Robert $\% 20$ Vischer $\% 20(1873) \& \mathrm{f}=$ false $\quad($ Erişim Tarihi: 01.04.2020).

Yavuzer, H. (2001). Yaygin ana-baba tutumlarn ana-baba okulu, (9. Basım), Ankara: Remzi Kitabevi.

Yıldırım, A. (2003). İlköğretim okulu yöneticilerinin empatik eğilimleri ve empatik becerileri ile çatışma yönetimi ve stratejileri arasındaki ilişki (Ankara ili örneği). (Yayımlanmamış Doktora Tezi), Ankara Üniversitesi, Sosyal Bilimler Enstitüsü, Ankara.

Yılmaz, V. (2004). Annelerin çocuk yetiştirme tutumlarına anneannelerin etkilerinin incelenmesi. (Yayımlanmamış Yüksek Lisans Tezi), Gazi Üniversitesi, Eğitim Bilimleri Enstitüsü, Ankara.

Yörükoğlu A.(2015). Çocuk ruh sağh̆ğı. (36. Basım). İstanbul: Özgür Yayın Dağıtım Ltd. Şti.

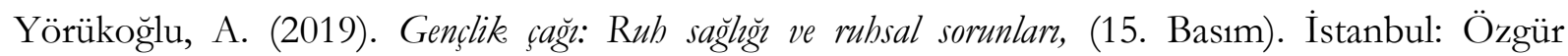
Yayınlar1.

Zahn-Waxler, C., Radke-Yarrow, M. \& King, R.A (1979). Child rearing and children's prosocial initiations toward victims of distress. Child Development, 50 (2), 319-330.

Zahn-Waxler, C., Radke-Yarrow, M., Wagner, E., \& Chapman, M. (1992). Development of concern for others. Developmental Psychology, 28 (1), 126-136.

Zhou, Q., Eisenberg, N., Losoya, S. H., Fabes, R. A., Reiser, M., Guthrie, I. K., Murphy, B. C., Cumberland, A. J. \& Shepard, S. A. (2002). The relations of parental warmth and positive expressiveness to children' empathy-related res-ponding and social functioning: A longitudinal study. Child Development, 73, 893-915. 